\title{
2 Facies mosaic in the inner areas of a shallow carbonate ramp (Upper 3 Jurassic, Higueruelas Fm, NE Spain)
}

\section{Abstract}

8 The internal facies and sedimentary architecture of an Upper Jurassic inner carbonate ramp were reconstructed after the analy9 sis and correlation of $14 \operatorname{logs}$ in a $1 \times 2-\mathrm{km}$ outcrop area around the Mezalocha locality (south of Zaragoza, NE Spain). The 10 studied interval is 10-16 m thick and belongs to the upper part of the uppermost Kimmeridgian-lower Tithonian Higuerue11 las Fm. On the basis of texture and relative proportion of the main skeletal and non-skeletal components, six facies and 12 12 subfacies were differentiated, which record subtidal (backshoal/washover, sheltered lagoon, and pond/restricted lagoon) to intertidal subenvironments. The backshoal/washover subenvironment is characterized by peloidal wackestone-packstone and grainstone. The lagoon subenvironment includes oncolitic, stromatoporoid, and oncolitic-stromatoporoid (wackestone and packstone) facies. The intertidal subenvironment is represented by peloidal mudstone and packstone-grainstone with fenestral porosity. Gastropod-oncolitic (wackestone-packstone and grainstone) facies with intercalated marl may reflect local ponds in the intertidal or restricted lagoon subenvironments. Detailed facies mapping allowed us to document seven sedimentary units within a general shallowing-upward trend, which reflect a mosaic distribution, especially for stromatoporoid and fenestral facies, with facies patches locally more than $500 \mathrm{~m}$ in lateral extent. External and internal factors controlled this heterogeneity, including resedimentation, topographic relief and substrate stability, combined with variations in sea-level. This mosaic facies distribution provides useful tools for more precise reconstructions of depositional heterogeneities, and this variability must be taken into account in order to obtain a solid sedimentary framework at the kilometer scale.

\section{Keywords Carbonate ramp · Facies mosaic · Intertidal · Sheltered lagoon · Higueruelas Fm · Upper Jurassic}

\section{Introduction}

Facies reconstructions of shallow-water areas of ancient epeiric, tropical-subtropical carbonate ramps are difficult to decipher due to the lack of good outcrop control of these complex internal ramp areas, and as a consequence, knowledge of the internal and external factors that controlled the sedimentary and facies evolution is limited (e.g., Burchette and Wright 1992; Bádenas and Aurell 2010). It is well known that in modern shallow-water carbonate platforms (e.g., the Bahamas), the depositional environments show a high variability in lateral extent and distribution (e.g., Rankey and Reeder 2010; Rankey 2016), and commonly display a complex pattern of depositional subenvironments

C. Sequero

csequero@unizar.es

1 Departamento Ciencias de la Tierra-IUCA, Universidad de Zaragoza, 50009 Saragossa, Spain with a patchy distribution (i.e., facies mosaics; Strasser and Védrine 2009).

The concept of a facies mosaic has been the subject of re-analysis by several authors (e.g., Schlager 2000, 2003; Burgess and Wright 2003; Burgess and Emery 2004; Wright and Burgess 2005; Védrine et al. 2007; Strasser and Védrine 2009; Bádenas et al. 2010; Rankey 2016). The carbonate facies models of Wilson (1975), Jones and Desrochers (1992) and Flügel (2004) described facies zones that give a general picture of the potential distribution of sedimentary environments and biota. On the other hand, Read (1985), Burchette and Wright (1992) and Pomar (2001) have emphasized the differences between the geometries of carbonate ramps and other kinds of carbonate platform, and discussed their implications for the facies distribution of marine carbonate systems. Wright and Burgess (2005) pointed out the high temporal and spatial variability of depositional environments that leads to facies mosaics, which correspond to reality better than the linear arrangement of facies belts shown

\begin{tabular}{|l|l|l|l|l|}
\hline Journal : Large 10347 & Article No : 521 & Pages : 23 & MS Code : FACI-D-17-00067 & Dispatch : 23-1-2018 \\
\hline
\end{tabular}


in many models. This is the case with the complex spatial variation and associated vertical stacking of peritidal carbonate facies at the sub-meter scale, which reflect the interplay between intrinsic factors specific to the environments of deposition (Verwer et al. 2009; Bádenas et al. 2010), such as the existence of preferential carbonate-producing areas, sediment redistribution caused by hydrodynamic conditions, or local depositional relief (Ginsburg 1971; Pratt and James 1986), and external eustatic and tectonic controls, such as sea-level changes controlled by Milankovitch orbital forcing (Goldhammer et al. 1990; Lehrmann and Goldhammer 1999; Strasser et al. 1999). Accordingly, some authors attribute vertical facies stacking to random migration of depositional environments and stress the importance of stochastic processes during sediment accumulation in modern carbonate settings, questioning the existence of meter-scale shallowing-upward cyclicity (Drummond and Wilkinson 1993; Wilkinson et al. 1996; Wilkinson and Drummond 2004).

A number of studies have tested the complex distribution of facies on carbonate platforms: Gischler and Lomando (1999) documented the high complexity of facies distribution of isolated carbonate platforms in Belize; Riegl and Piller (1999) mapped the great lateral variability of coral carpets, reefs and carbonate sand in Safaga Bay (Egypt), and Rankey (2002) discussed the fractal nature of facies patches on the tidal flats of Andros Island (Bahamas). Strasser and Védrine (2009) showed the facies heterogeneities on a shallow-water carbonate ramp of the Oxfordian (Late Jurassic) of the Swiss Jura Mountains and the facies evolution along selected time-lines, underlining that ancient, shallow-water carbonate systems are as complex as modern ones. Verwer et al. (2009) also noted a patchy distribution for a shoalbarrier complex in a Lower Jurassic platform in Djebel Bou Dahar (High Atlas, Morocco), and observed the higher lateral continuity of facies when the relative water depth increased during flooding of the platform top.

The studied examples have shown that the complex relationship of internal and external factors controlling facies distribution varies greatly with the nature of the carbonate systems (i.e., carbonate-producing biota). To increase our knowledge and understanding of the concept of a facies mosaic, therefore, further detailed case studies are required. The main purpose of this work is to investigate the lateral continuity and facies variability of the inner areas of a shallow carbonate ramp that developed around the Kimmeridgian-Tithonian transition (Higueruelas Fm, Iberian Basin), which reflect a mosaic facies distribution, and to decipher the depositional controls. The lateral and vertical distribution of facies are revealed through an extensive sedimentological analysis of the outcrops located near the Mezalocha locality (northeast Spain). Previous works on the Upper Jurassic Higueruelas Fm in northeastern Iberia have documented a spatial distribution of facies based on
Fig. 1 a Paleogeography of Western Europe during the late Kimmeridgian (modified from Dercourt et al. 1993). b Facies distribution around the Kimmeridgian-Tithonian transition in the northern Iberian Basin with the location of Mezalocha and the other logged outcrops (from Ipas et al. 2004). c Vertical facies evolution for the Higueruelas Formation in Mezalocha (from Ipas et al. 2004). The upper part corresponds to the succession studied in this work. d Field view of the Higueruelas Fm and the underlying Loriguilla Fm. The lower boundary of the Higueruelas Fm corresponds to a basin-wide discontinuity surface. The dashed red line overlaps the stratigraphic section studied here

the correlation of separate stratigraphic logs (Aurell and Meléndez 1986, 1987; Cepriá et al. 2002; Ipas et al. 2004). Here, a more detailed scheme of the spatial relationships of the facies is presented by means of the exhaustive facies mapping and physical tracing of a number of sharp, reference bedding planes for correlation of the stratigraphic logs. The mosaic facies distribution can provide useful tools for achieving precise reconstructions of depositional heterogeneities in similar settings, and an understanding of the factors controlling these facies mosaics may be relevant to the interpretation of the vertical stacking of facies in high-frequency cycles and the correlation of cycles at larger scales.

\section{Geological setting}

During the Late Jurassic, shallow epeiric seas covered wide areas of western Europe, and carbonate sedimentation was dominant in the platforms facing the Tethys Ocean to the east (Dercourt et al. 1993). This was the case with the wide carbonate ramp that developed in the Iberian Basin, east of the Iberian Massif (Fig. 1a, b; Aurell et al. 1994, 2002; Bádenas and Aurell 2001). The sedimentary evolution of this carbonate ramp during the Kimmeridgian-Tithonian transition in this carbonate ramp was characterized by a major regression controlled by the tectonic uplift of the Iberian Massif combined with a long-term regional fall in sea-level (Bádenas and Aurell 2001; Aurell et al. 2003).

In the central Iberian Basin, three third-order depositional sequences have been recognized for the Kimmeridgian-lower Tithonian sedimentary succession (Kim1, Kim2 and Ti1 sequences; Bádenas and Aurell 2001; Aurell et al. 2010). The stratigraphic succession studied in the present work belongs to the upper Kimmeridgian-lower Tithonian Ti1 sequence and is located in the north-central part of the Iberian Basin (Fig. 1b). Here, the Til sequence is represented by the shallow-water carbonate deposits of the Higueruelas Fm, which records a wide range of grain-supported textures with variable proportions of skeletal remains (e.g., corals, stromatoporoids, foraminifera, molluscs, serpulids, echinoderms) and non-skeletal components (oncoids, 


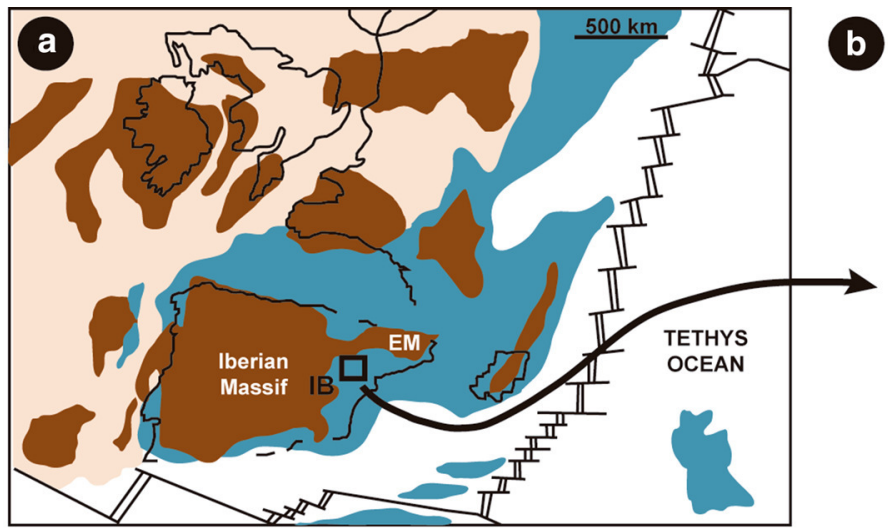

Exposed land $\square$ Siliciclastic shelf \& basins

Shallow carbonate platforms

$\mathrm{IB}=$ Iberian Basin $\quad \mathrm{EM}=$ Ebro Massif Slope and deep basin

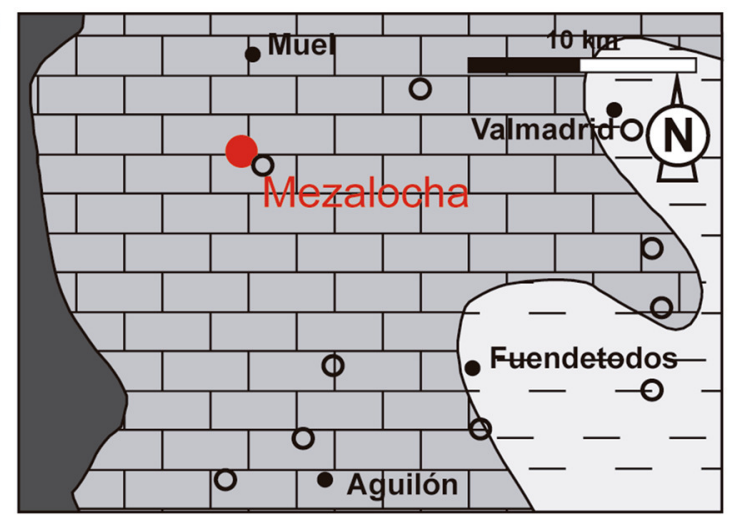

Land areas $\square$ Inner - middle ramp $\square$ Middle ramp

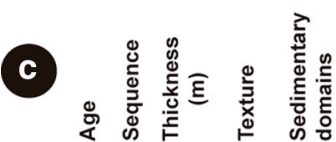

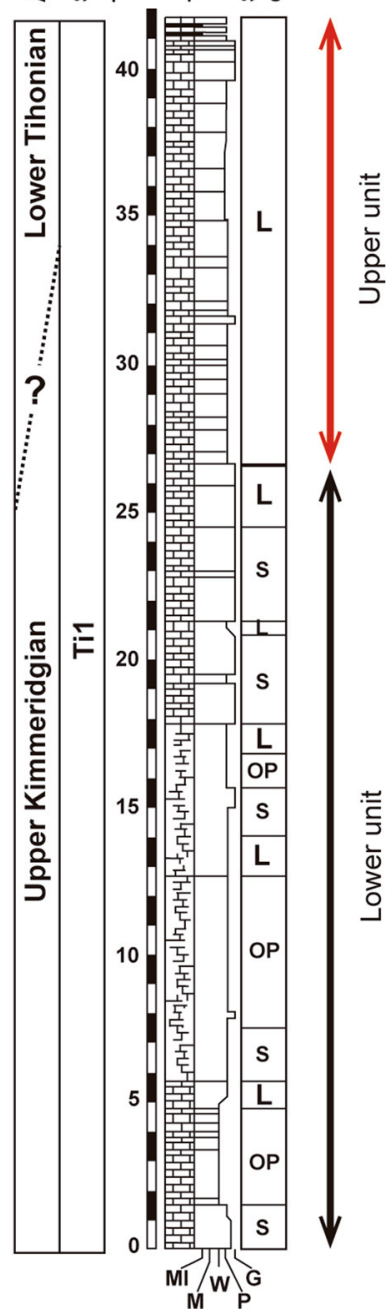

OP: Open platform: mainly peloidal wackestone-packstone

S: Shoal: mainly oncolitic and oolitic-peloidal grainstone

L: Lagoon: mainly peloidal packstone and oncolitic and stromatoporoid wackestone-packstone

MI: marl W: wackestone G: grainstone

M: mudstone

P: packstone

\section{d}

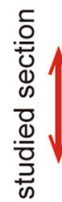

$\uparrow$

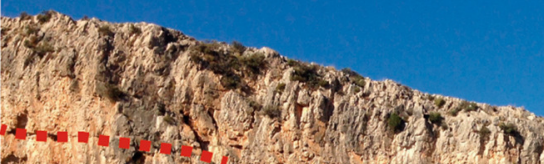

1.t.

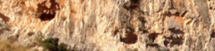

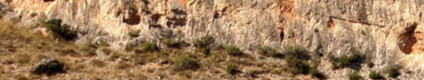

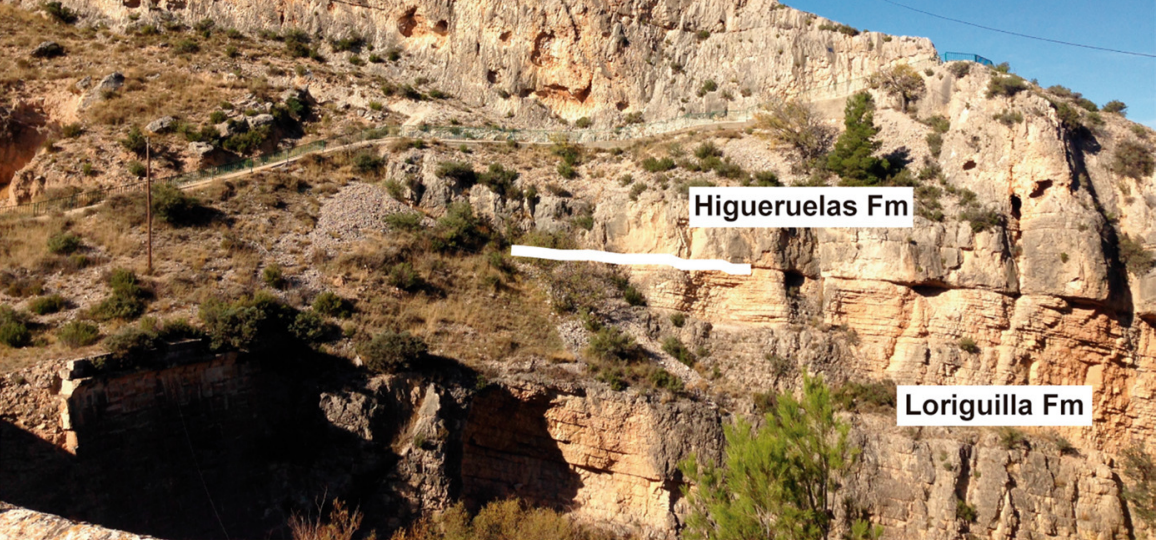


ooids, peloids, aggregate grains) (e.g., Aurell and Meléndez 1986; Ipas et al. 2004).

In the studied outcrops located around Mezalocha, the Higueruelas Fm is $40-50 \mathrm{~m}$ thick and displays two main lithological units (Fig. 1c): (1) a lower unit ( $26 \mathrm{~m}$ thick), characterized by very thick beds ( $1 \mathrm{~m}$ to several meters thick) of limestone which represent an alternation of ooliticpeloidal and oncolitic shoal facies, shallow peloidal openplatform and local peloidal lagoon facies; and (2) an upper unit ( $15 \mathrm{~m}$ thick), characterized by $\mathrm{dm}$ - to $\mathrm{m}$-thick tabular limestones, mostly comprising lagoon facies (Ipas et al. 2004), which constitutes the subject of the present study. The lower boundary of the Higueruelas Fm corresponds to the regional discontinuity surface that developed on top of the well-bedded dm-thick lime mudstones of the Loriguilla Fm (Aurell et al. 2010; Fig. 1d). The upper boundary of the Higueruelas Fm in the study area is a sharp erosive contact with the Neogene continental units of the Ebro Basin (lower Miocene tectonosedimentary unit T5; Muñoz et al. 2002).

In the Mezalocha area, the Kimmeridgian-Tithonian boundary is assumed to be located in the upper part of the Higueruelas Fm (Fig. 1c). Scarce mid-late Kimmeridgian ammonites are found in the open-platform facies of the underlying Kim2 sequence (i.e., upper Loriguilla Fm) in Aguilón and Fuendetodos outcrops (see Fig. 1b for location). Significant recorded ammonites are Progeronia breviceps (Quenstedt) and Aspidoceras longispinum apeninicum (Sowerby) in the middle and upper part of the Loriguilla Fm, respectively (Bádenas et al. 2003). In addition, the presence of Anchispirocyclina lusitanica (Egger) indicates a Tithonian age for the overlying terrigenous unit outcropping in nearby areas (i.e., Villar del Arzobispo Fm, Aguilón area, see Fig. 1b: Ipas et al. 2007; Hernández-Samaniego and Ramírez-Merino 2005).

\section{Methodology}

The present study focuses on the upper ( $15 \mathrm{~m}$ thick) unit of the Higueruelas Fm in the outcrops located around the locality of Mezalocha, which represent an area of $1 \times 2 \mathrm{~km}$ in extent (Fig. 2). Here, a low tectonic dip $\left({ }^{<} 20^{\circ}\right)$ and good outcrop conditions in small active and inactive quarries allow an accurate analysis of the uppermost Kimmeridgian-lower Tithonian inner ramp lagoonal facies. Regarding the general paleogeographic reconstruction of the Iberian Basin during this time interval (Fig. 1b), the distal facies for the studied Mezalocha outcrops are thought to be located to the southeast.

Facies analysis was based on a bed-by-bed field description of 14 closely spaced sedimentological logs (M1 to M14 in Fig. 2), and this was complemented with the petrographic description of rock samples in 111 thinsections and 438 polished slabs (two samples/m on average). Petrographic analysis allowed us to determine the semi-quantitative proportion of skeletal and non-skeletal components, as well as the texture following the Dunham (1962) classification. For the description of non-skeletal grains, the proposed nomenclature for oncoids (Dahanayake 1977), ooids (Strasser 1986) and peloids (Flügel 2004) was adopted.

The physical tracing of bedding planes was carried out in order to decipher their geometry and lateral continuity. Facies and subfacies were differentiated in the studied logs mainly on the basis of the texture and the relative proportion of the main skeletal and non-skeletal components. Identifying the lateral facies changes between logs was helped by the recognition of a number of continuous sharp bedding planes physically traced along the outcrops, which were considered to be isochrones at outcrop-scale. In areas without lateral continuity of outcrop, lateral facies correlation was accomplished using the best fit of facies between $\log$ based on vertical facies distribution. The sedimentary features of facies and subfacies and their lateral and vertical stacking patterns were the key criteria for their paleoenvironmental interpretation.

\section{Bedding pattern}

The limestones of the upper part of the Higueruelas Fm are arranged in tabular beds (0.1-2 $\mathrm{m}$ in thickness), with sharp to diffuse bedding planes (Figs. 3 and 4). In particular, the physical tracing of bedding planes allowed the identification of six sharp bedding planes that are continuous at outcrop scale, some of which correspond to Fe-enriched surfaces (see 1-6 in Figs. 3a and 4). Locally, cm-thick marly beds overlie these sharp surfaces. These sharp bedding planes allowed us to document seven sedimentary units (A-G in Fig. 3a, b), with an average thickness of between 0.6 and $4 \mathrm{~m}$. Lateral variations in thickness are found within the sedimentary units, especially for B (0.6-3 m), C (1.2-3.4 m), and D (0.7-4 m).

Varying numbers of diffuse bedding planes were identified in the individual logs within the seven sedimentary units. These surfaces cannot be physically traced at outcrop scale, reflecting the fact that they correspond to discontinuous bedding planes. As no evidence of lenticular bedding geometries has been observed in the outcrops, the proposed correlation of the diffuse bedding surfaces (Fig. 3a) suggests an aggradational pattern of these beds similar to that of the sedimentary units A-G, instead of a lateral pinching out of beds. 


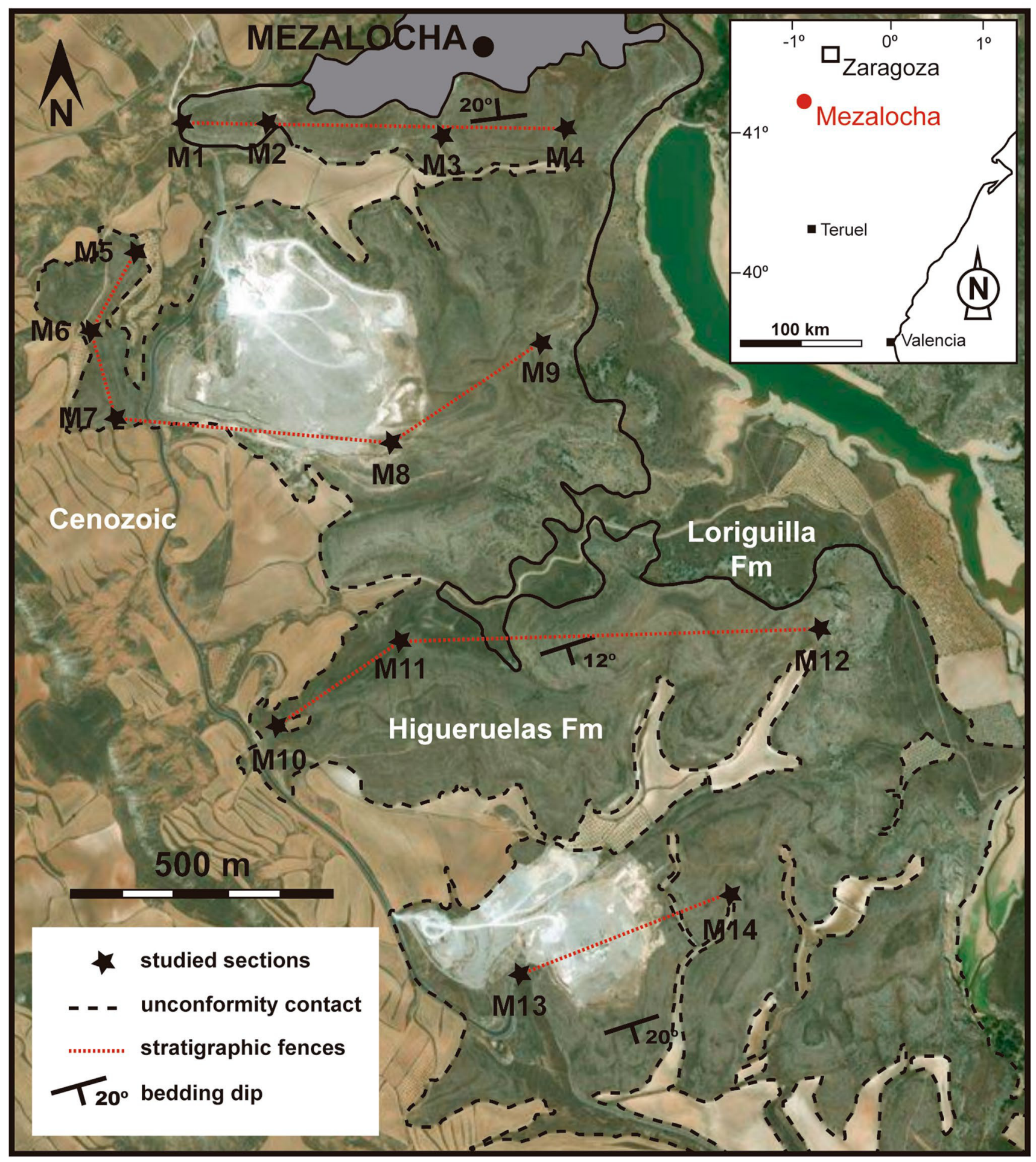

Fig. 2 Location of the studied sections (M1 to M14) across the Mezalocha outcrops, located south of Zaragoza (northeast Spain) 
a
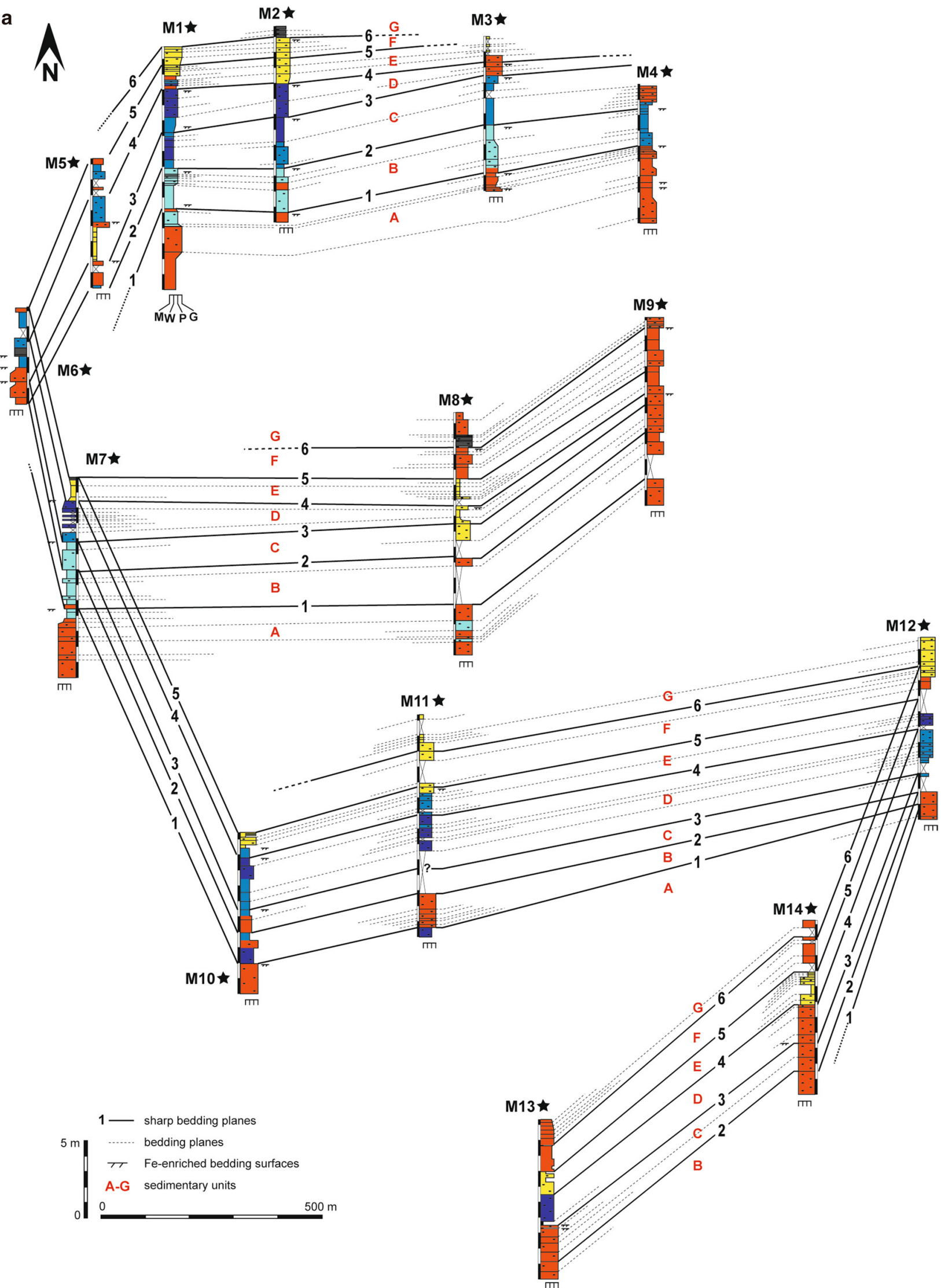

\begin{tabular}{|l|l|l|l|l|}
\hline Journal : Large 10347 & Article No : 521 & Pages : 23 & MS Code : FACI-D-17-00067 & Dispatch : 23-1-2018 \\
\hline
\end{tabular}


4 Fig. 3 a Vertical distribution of facies and bedding surfaces in the 14 stratigraphic logs (M1 to M14) in the Mezalocha outcrops. The correlation between logs is based on the physical tracing of six sharp bedding planes (black lines), which have made it possible to document seven sedimentary units $(\mathrm{A}-\mathrm{G})$. The proposed correlation of bedding surfaces within the sedimentary units is also indicated (dashed lines). b Correlation panels showing the lateral and vertical facies changes between the 14 stratigraphic logs. $\mathbf{c}$ Facies and subfacies relationships

\section{Facies analysis}

On the basis of their components, textures and sedimentary structures, six facies and 12 subfacies were distinguished across the entire study area (Table 1, Figs. 5, 6, 7). Their vertical and lateral distribution within the seven sedimentary units A-G, is shown in Fig. 3b. Each facies is characterized by a suite of dominant carbonate grains, and their corresponding subfacies are mainly differentiated according to the texture and proportion of dominant grains: (1) peloidal (P) facies encompasses grainstone (Pg) and wackestone-packstone (Pwp) subfacies; (2) oncolitic (O) facies includes packstone $(\mathrm{Op})$ and wackestone $(\mathrm{Ow})$ subfacies; (3) stromatoporoid (S) facies comprises packstone ( $\mathrm{Sp}$ ) and wackestone ( $\mathrm{Sw}$ ) subfacies; (4) oncolitic-stromatoporoid (OS) facies encompasses packstone (OSp) and wackestone (OSw) subfacies; (5) fenestral (F) facies includes packstone-grainstone (Fpg) and mudstone (Fm) subfacies; and (6) gastropod-oncolitic $(\mathrm{G})$ facies comprises grainstone $(\mathrm{Gg})$ and wackestone-packstone (Gwp) subfacies.

On the basis of their sedimentary features and the lateral and vertical facies relationships, each facies and subfacies was assigned to a particular subenvironment within the inner domains of the studied carbonate ramp: i.e., backshoal/ washover, sheltered lagoon, intertidal and local subtidal pond/restricted lagoon subenvironments.

\section{Backshoal/washover facies}

The backshoal/washover deposits are represented by the peloidal (P) facies (Fig. 5a-d). This facies is generally arranged in dm-to m-thick tabular to irregular beds, with parallel and local $\mathrm{cm}$-thick sets of planar cross-lamination, local mm- to cm-thick oncolitic, skeletal and oolitic laminae with normal gradation, and common bioturbation. It is characterized by an abundance of irregular and poorly sorted lithic peloids, and variable proportions of oncoids, ooids and skeletal grains (Table 1). The peloidal Pg subfacies (Fig. 5b-d) contains a higher proportion of ooids (type 1 and 1/3 ooids) compared with the peloidal Pwp subfacies (Fig. 5a), which has more abundant type I and II oncoids (Fig. 7a). The main skeletal components are bivalves, echinoderms, brachiopods, Tubiphytes, dasycladacean algae, gastropods and foraminifera (lituolids, textulariids and miliolids).
This facies changes laterally and vertically into almost all facies and subfacies (see Fig. 3b, c). The lateral and vertical relationships of the $\mathrm{P}$ facies, the grain-supported texture, the mixture of different types of high-energy non-skeletal grain (lithic peloids, type 1 and 1/3 ooids and type I and II oncoids; e.g., Flügel 2004; Strasser 1986; Dahanayake 1977), and the presence of parallel- and planar cross-lamination, and $\mathrm{cm}$-thick accumulations of ooids, oncoids and bioclasts, indicate that the $\mathrm{P}$ facies corresponds to resedimented sediments (washover) as well as backshoal sediments of distal oolitic-peloidal and oncolitic banks or shoals. These shoal facies are not registered in the studied upper unit of the Higueruelas Fm, but they have been documented by Aurell and Meléndez (1986) and Ipas et al. (2004) in the lower part of the underlying unit in the Mezalocha outcrops (see Fig. 1c). The variation in texture and proportion of dominant carbonate grains between the Pg and Pwp subfacies is thought to be due to different high-energy conditions and the influence of the distal banks or shoals. The grainstone texture and the predominance of lithic peloids and type 1 and $1 / 3$ ooids in the Pg subfacies reflect high-energy conditions (e.g., Flügel 2004; Strasser 1986), i.e., backshoal areas close to the distal oolitic-peloidal shoals or washover deposits. By contrast, the presence of carbonate mud and the predominance of oncoids in the Pwp subfacies indicate deposition in lower-energy conditions, probably in backshoal areas of oncolitic-dominated shoals closer to the lagoon. Common bioturbation, the presence of aggregate grains and the micritization of skeletal and non-skeletal components reflect stabilization in the backshoal environment (Table 1; e.g., Bádenas and Aurell 2010).

\section{Sheltered lagoon facies}

The sheltered lagoon subenvironment includes the oncolitic (O), stromatoporoid (S) and oncolitic-stromatoporoid (OS) facies that are complexly laterally and vertically related (Fig. 3b, c), although the lateral relationships of the grainsupported subfacies (Op-OSp-Sp) and muddy subfacies $(\mathrm{Ow}-\mathrm{OSw}-\mathrm{Sw})$ dominate. These facies are generally arranged in $\mathrm{dm}$ - to $\mathrm{m}$-thick beds and usually show bioturbation (Table 1).

\section{Oncolitic (0) facies}

This is characterized by an abundance of type III oncoids (Figs. 5e, f and 7b), which display bioclastic cores and thick crusts mainly composed of an alternation of organismbearing encrustations (e.g., Bacinella irregularis, Lithocodium aggregatum, Cayeuxia-Ortonella, Girvanella, Thaumatoporella parvovesiculifera) and micritic laminae. The oncoids are surrounded by a fine-grain-sized fraction composed mainly of lithic peloids. The Op and Ow subfacies are

\begin{tabular}{|l|l|l|l|l|}
\hline Journal : Large 10347 & Article No : 521 & Pages : 23 & MS Code : FACI-D-17-00067 & Dispatch : 23-1-2018 \\
\hline
\end{tabular}


i

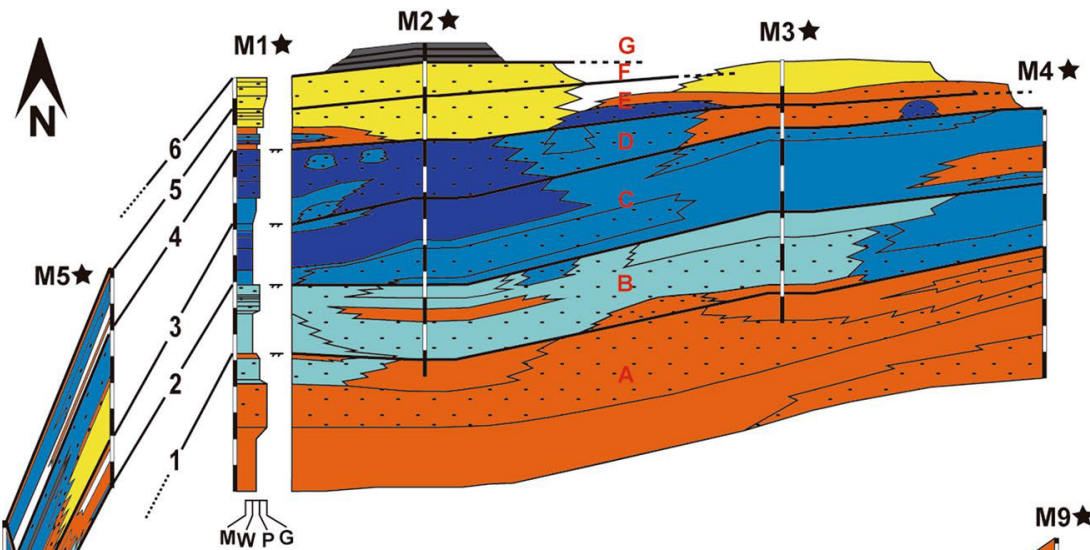

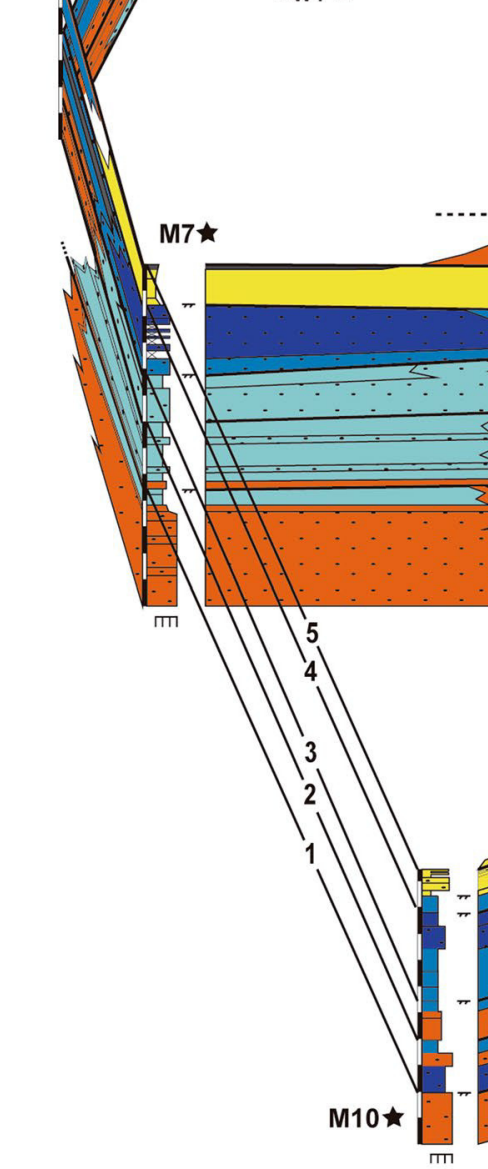

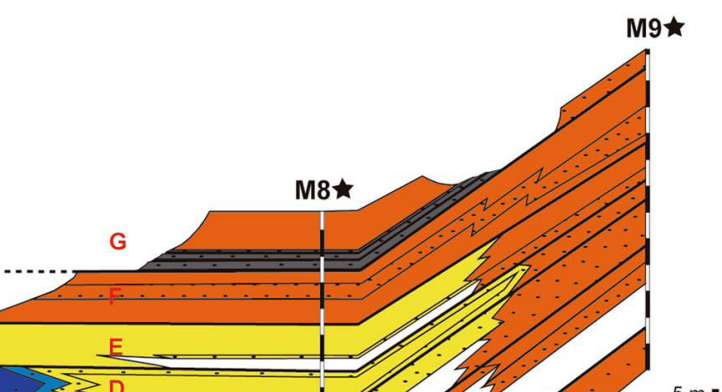

FACIES AND SUBENVIRONMENTS

Sheltered lagoon

$\square$ Oncolitic W (Ow)

- Oncolitic P (Op)

Oncolitic-stromatoporoid W (OSW)

Oncolitic-stromatoporoid P (OSp)

Stromatoporoid W (Sw)

Stromatoporoid P (Sp)

Backshoal/washover

$\square$ Peloidal W-P (Pwp)

Peloidal $\mathrm{G}(\mathrm{Pg})$

Pond/ restricted lagoon

Gastropod-oncolitic W-P (Gwp)

Gastropod-oncolitic $\mathrm{G}(\mathrm{Gg})$

\section{Intertidal}

$\square$ M with fenestral porosity ( $F m$ )

- P-G with fenestral porosity (Fpg)

\section{M: mudstone \\ W: wackestone \\ P: packstone}

G: grainstone

$5 \mathrm{~m} 1-$ sharp bedding planes

TFe-enriched bedding surfaces

A-G sedimentary units
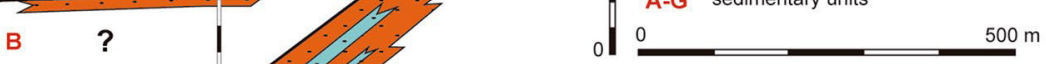

0
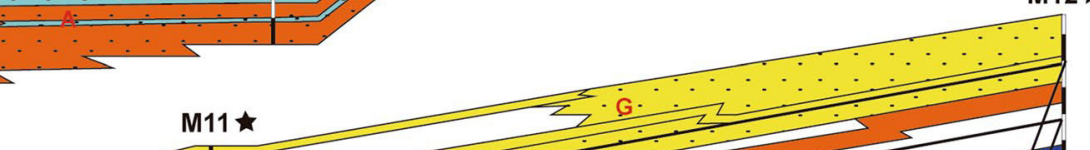

C
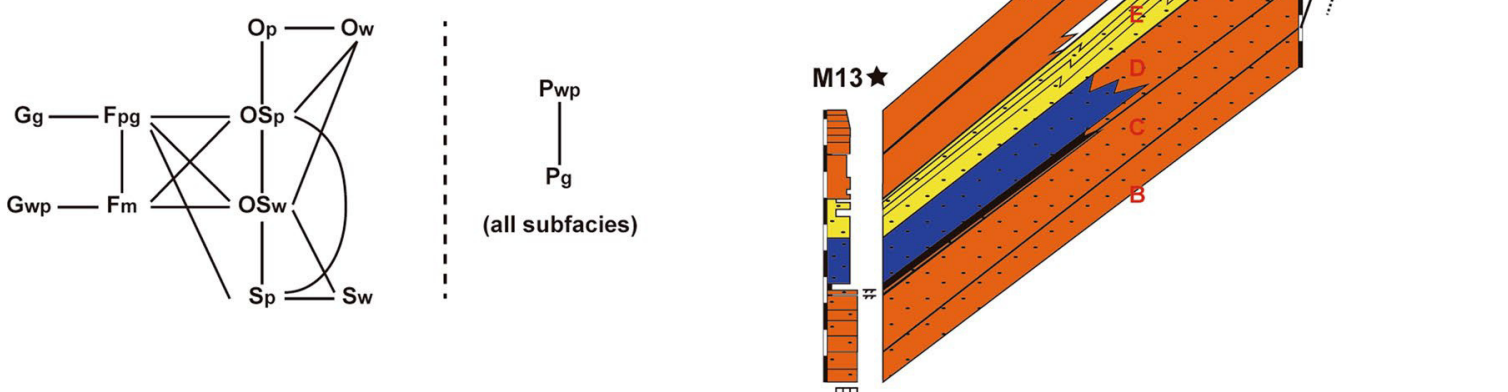

Fig. 3 (continued)

\begin{tabular}{|l|l|l|l|l|}
\hline Journal : Large 10347 & Article No : 521 & Pages : 23 & MS Code : FACI-D-17-00067 & Dispatch : 23-1-2018 \\
\hline
\end{tabular}



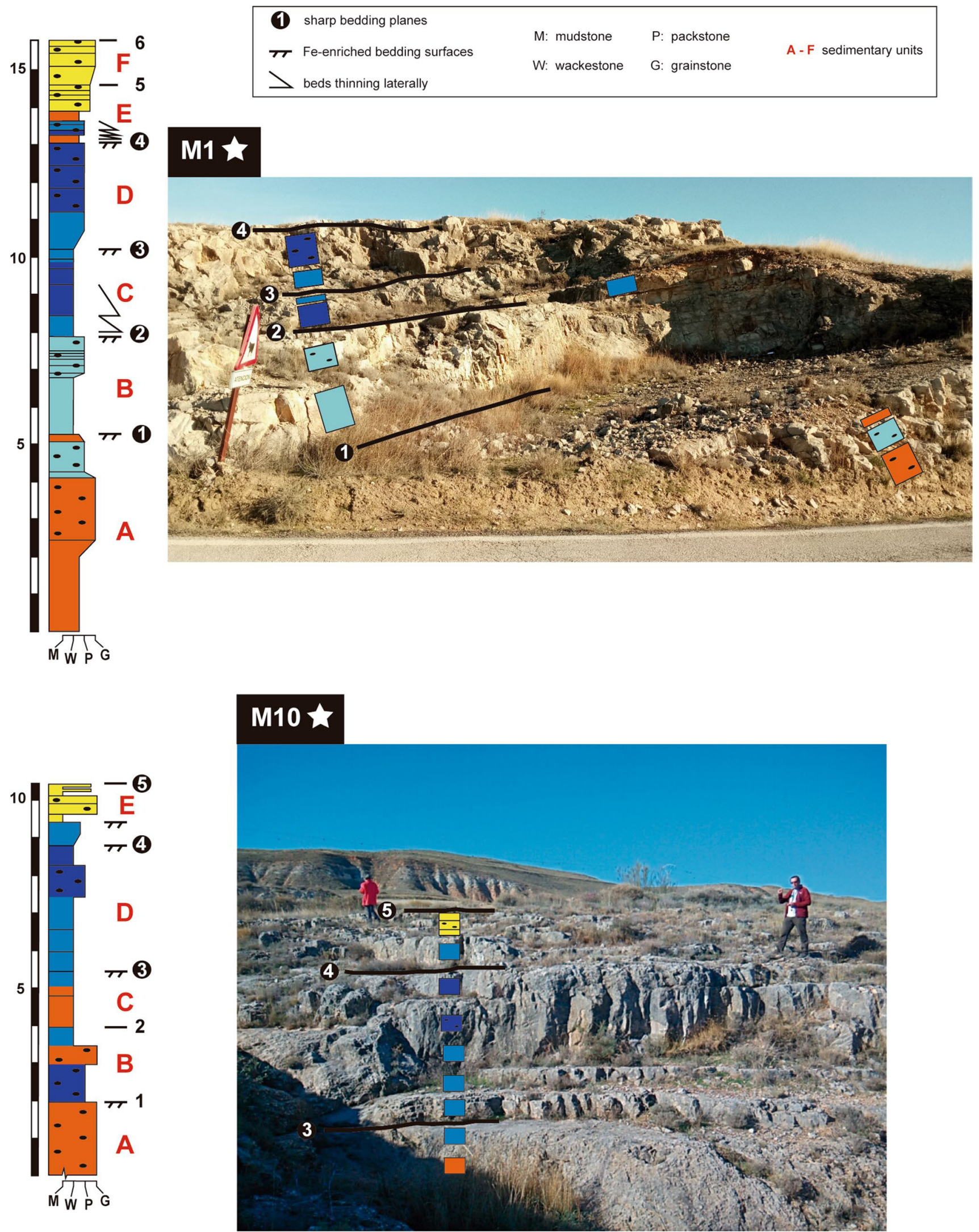

Fig. 4 Field view of sharp bedding planes (numbers in circles) recognized in the stratigraphic sections M1 and M10. These bedding planes can be traced across the entire study area. Notice the irregular aspect of stromatoporoid and oncolitic-stromatoporoid facies, versus the tabular aspect of oncolitic facies

\begin{tabular}{|l|l|l|l|l|}
\hline Journal : Large 10347 & Article No : 521 & Pages : 23 & MS Code : FACI-D-17-00067 & Dispatch : 23-1-2018 \\
\hline
\end{tabular}




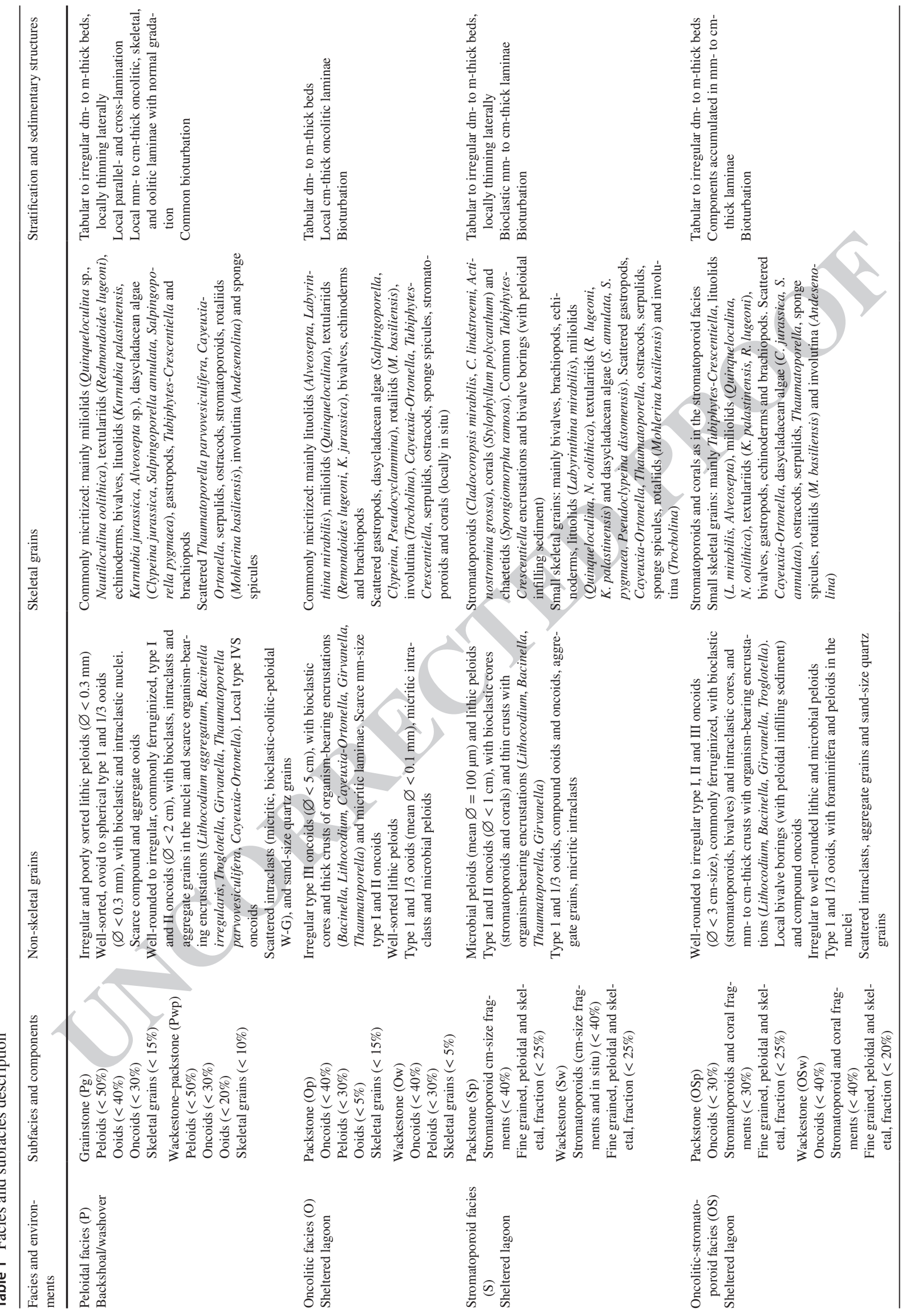




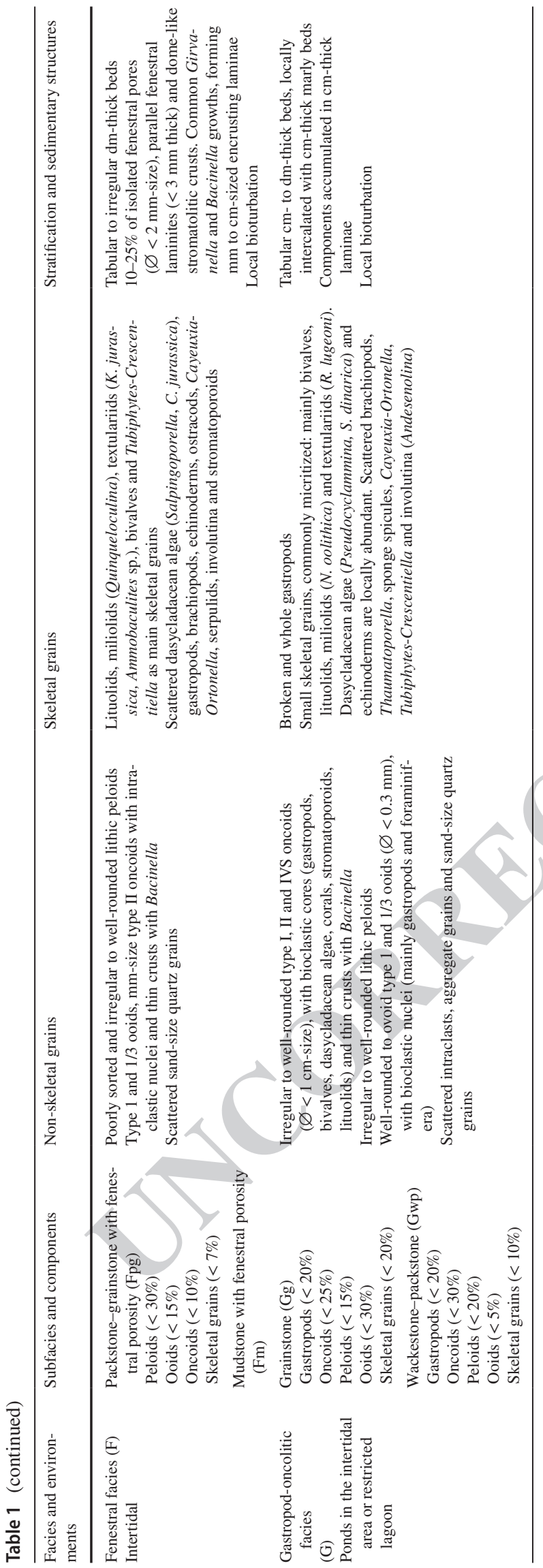

differentiated on the basis of the texture and on the presence of type 1 and $1 / 3$ ooids in the oncolitic packstone (Op) subfacies (Fig. 5e, f). The skeletal content is low but includes a high diversity of bioclasts, mainly foraminifera, bivalves, echinoderms and brachiopods, which are commonly micritized (Table 1).

The predominance of large and irregular type III oncoids, bioturbation and the variety of skeletal components reflect deposition in non-restricted shallow waters in generally calm conditions with intermittent high-energy conditions. During long periods under calm conditions, oncolitic bacterial growth (i.e., Bacinella, Lithocodium, Cayeuxia-Ortonella, Girvanella, Thaumatoporella) and micritization of skeletal grains is favored. Short high-energy periods favor the generation of micritic laminae in the oncoids (Dahanayake 1977). The presence of type 1 and $1 / 3$ ooids in the Op subfacies and type I and II oncoids is due to the variable input of resedimented grains from the laterally related facies, mainly from the backshoal/washover peloidal (P) facies (Fig. 3b, c).

\section{Stromatoporoid (S) facies}

The stromatoporoid (S) facies is generally arranged in $\mathrm{dm}$ - to $\mathrm{m}$-thick, irregular and tabular beds, and is characterized by an abundance of broken and in situ stromatoporoids (commonly Cladocoropsis), along with $\mathrm{cm}$-size fragments of corals and chaetetids. Tubiphytes-Crescentiella encrustations are common on stromatoporoids (Figs. $5 \mathrm{~g}$, $\mathrm{h}$ and $7 \mathrm{~d}$ ). The fine-grain-sized fraction is composed of peloids (microbial and lithic peloids) and small skeletal grains, mainly of bivalves, brachiopods, echinoderms, foraminifera and dasycladacean algae (Table 1). Type I and II oncoids and type 1 and $1 / 3$ ooids are also recognized in low proportions. The stromatoporoid packstone (Sp) and wackestone ( $\mathrm{Sw}$ ) subfacies are differentiated on the basis of the texture and the presence of in situ stromatoporoids in $\mathrm{Sw}$ (Fig. 5g). Bioturbation and mm-thick bioclastic accumulations are more common in $\mathrm{Sp}$.

The stromatoporoid facies forms patches, locally more than $500 \mathrm{~m}$ in lateral extent and commonly related to oncolitic-stromatoporoid (OS) facies (Fig. 3b). The usual presence of Cladocoropsis in lagoonal facies has been highlighted by previous authors (e.g., Flügel 1974; Turnsek et al. 1981; Leinfelder et al. 2005; Aurell et al. 2012). Microbial peloids suggest high microbial activity, especially in $\mathrm{Sw}$ subfacies, related to lower-energy areas within the lagoon. The relatively low abundance of corals compared to stromatoporoids in the $\mathrm{S}$ facies seems to be related to the hydrodynamic conditions within the depositional environment; Cladocoropsis meadows and other stromatoporoids can be widespread in lagoonal areas as they are adapted to overheated waters, strong abrasion and probably oligotrophic conditions (Leinfelder et al. 2005). The presence of algae 

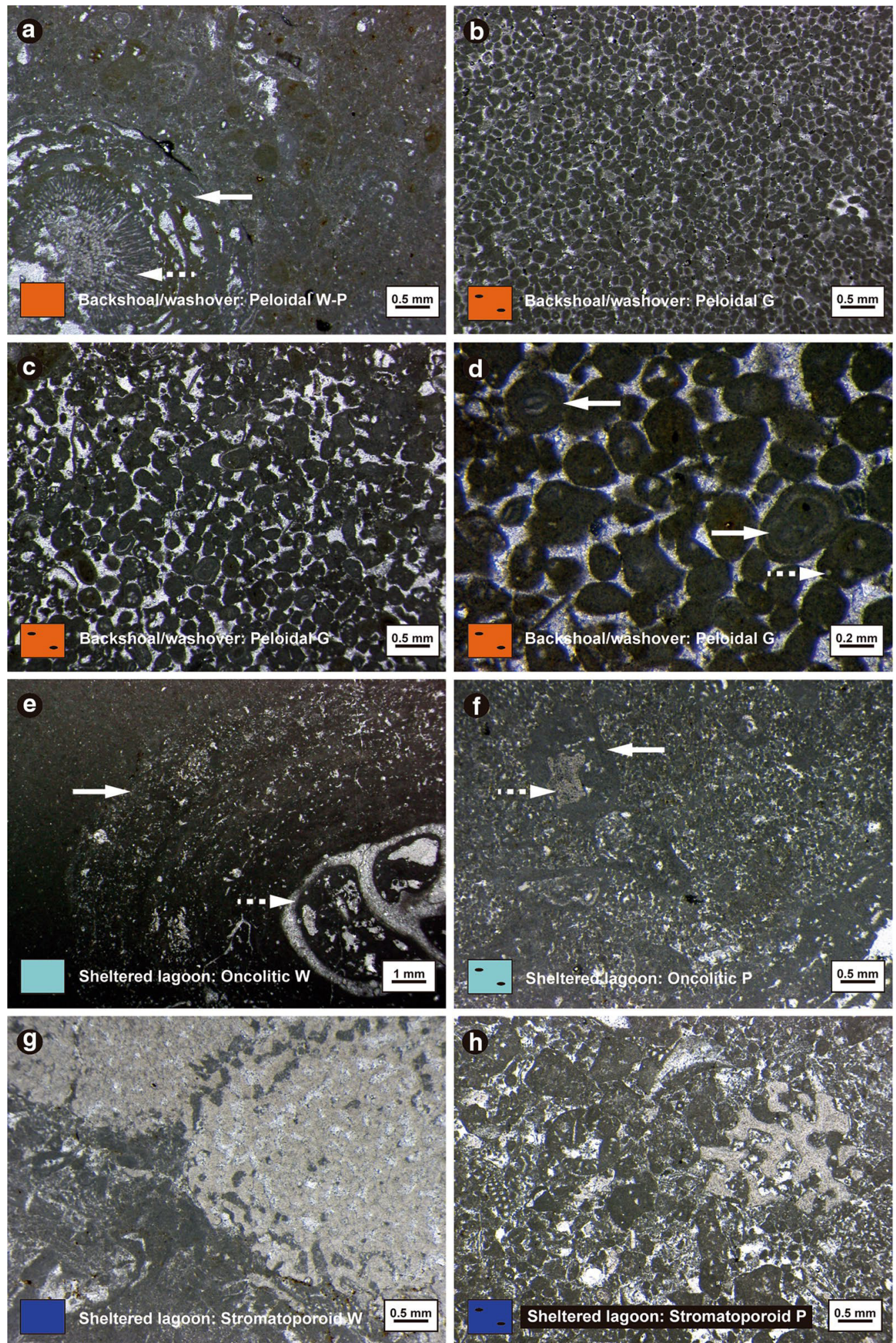
indicates well-oxygenated, normal marine waters. Vari-

388 able proportions of lithic peloids, gastropods, type I and II oncoids and type 1 and $1 / 3$ ooids show the influence of the laterally related oncolitic-stromatoporoid (OS) and peloidal (P) facies (Fig. 3b, c). 
४Fig. 5 a-d Peloidal facies (backshoal subenvironment). a Peloidal wackestone-packstone subfacies showing poorly sorted lithic peloids, some bioclasts and type II oncoids, with bioclastic core (CayeuxiaOrtonella, dashed arrow) and micritic and grumose laminae (white arrow) displaying sparitic patches of Bacinella-Lithocodium. b-d Proximal backshoal subfacies composed of well-sorted (b) to poorly sorted (c) lithic peloids, type 1 and 1/3 ooids (white arrows in d) and compound and aggregate grains (dashed arrow in d). e, f Oncolitic wackestone (e) and packstone (f) subfacies (lagoon subenvironment), with type III oncoids showing thick crusts with micritic and sparitic laminae of Bacinella and Girvanella (white arrow in e), lithic peloids and type II oncoids (white arrow in f). Oncoids display bioclastic cores (gastropod for the type III oncoid in e, dashed arrow; echinoderm for the type II oncoids in $\mathbf{f}$, dashed arrow). $\mathbf{g}, \mathbf{h}$ Stromatoporoid wackestone (g) and packstone (h) subfacies (lagoon subenvironment), showing fragments of Cladocoropsis, poorly sorted peloids, microbial peloids and micritized bioclasts

\section{Oncolitic-stromatoporoid (OS) facies}

The oncolitic-stromatoporoid (OS) facies is an intermediate facies of $\mathrm{O}$ and $\mathrm{S}$ facies, characterized as it is by a similar proportion of oncoids (types I, II and III) and stromatoporoid and coral fragments (Fig. 6a, b). The fine-grain-sized fraction is mainly composed of peloids (lithic and microbial peloids) and small skeletal grains, mainly comprising debris from Tubiphytes-Crescentiella, foraminifera, bivalves, gastropods, echinoderms and brachiopods (Table 1). The OSw and OSp subfacies are differentiated on the basis of texture and a higher proportion of type 1 and $1 / 3$ ooids in OSp (Fig. 6b). Bioturbation and $\mathrm{mm}$ - to $\mathrm{cm}$-thick accumulations of coarse grains are also more common in this subfacies. By contrast, oncoids and stromatoporoid and coral fragments are more abundant in OSw subfacies.

The OS facies represents a transition between the oncolitic $(\mathrm{O})$ and stromatoporoid $(\mathrm{S})$ facies, with which it is complexly related (e.g., unit D in Fig. 3b; see the complex O-OS-S facies relationship in Fig. 3c). These facies relationships reflect the fact that the OS facies are lagoonal sediments surrounding the stromatoporoid patches ( $\mathrm{S}$ facies; e.g., unit D in Fig. 3b). The higher proportion of type 1 and $1 / 3$ ooids and $\mathrm{mm}$ - to $\mathrm{cm}$-thick laminae in the OSp subfacies reflects the greater influence of resedimented grains from backshoal areas ( $\mathrm{P}$ facies) compared to OSw. The higher proportion of oncoids and stromatoporoid and coral fragments in the OSw subfacies indicates lower energy-conditions and the greater influence of the other muddy lagoonal subfacies ( $\mathrm{Ow}$ and $\mathrm{Sw})$.

\section{Intertidal facies}

The intertidal facies is represented by the fenestral (F) facies (Fig. 6c-e). This facies is generally arranged in dm-thick tabular to irregular beds, and is characterized by the presence of fenestral pores and lithic peloids, and in lower proportions ooids, oncoids and skeletal grains, mainly of foraminifera, bivalves and Tubiphytes-Crescentiella (Table 1). The packstone-grainstone (Fpg) subfacies contains a higher proportion of peloids, type 1 and 1/3 ooids, type II oncoids and bioclasts compared with the mudstone (Fm) subfacies (Fig. 6c, d). Girvanella and Bacinella growths (Fig. 6e) forming mmto $\mathrm{cm}$-sized lamina packages, parallel fenestral laminites and dome-like stromatolitic crusts are also common.

This facies represents both the subaerial exposure of mud-supported and grain-supported lagoonal and washover sediments (Op, OSp, OSw, and Sp subfacies), as indicated by the presence of fenestral porosity and its patchy distri-AQ1 7 bution ( $200 \mathrm{~m}$ to more than $600 \mathrm{~m}$ in lateral extent), and a wider intertidal belt laterally related with muddy and grainy lagoonal sediments (Fig. 3b, c). The fenestral pores may be caused by the entrapment of air bubbles in the sediment by turbulent flows related to waves, algal activity or the drying and rapid precipitation of cements (e.g., Shinn 1968; Flügel 2004). The presence of Girvanella and Bacinella growths and dome-like stromatolitic crusts indicates microbial activity. Textural differences between the Fpg and Fm subfacies are due to the different facies being subjected to subaerial exposure (i.e., F patches) and the variable water energy and to the influence of sediment which is resedimented from surrounding areas (i.e., F intertidal belt).

\section{Ponds in the intertidal area or restricted lagoon facies}

This subenvironment is represented by the gastropodoncolitic (G) facies (Fig. $6 \mathrm{f}-\mathrm{h}$ ). This facies is generally arranged in $\mathrm{cm}$ - to dm-thick tabular beds, and has locally intercalated marl. It is characterized by a predominance of broken and whole gastropods and type I, II and IVS oncoids (Fig. 7c), with variable proportions of lithic peloids, type 1 and 1/3 ooids and small, commonly micritized skeletal grains, mainly of bivalves and foraminifera (Table 1). The gastropod-oncolitic Gwp subfacies has a higher proportion of lituolids (Fig. 6f), whereas ooids and skeletal grains in $\mathrm{cm}$-thick laminae are more abundant in the gastropodoncolitic Gg subfacies. The gastropod-oncolitic $\mathrm{G}$ facies is related laterally with the peloidal $(\mathrm{P})$ facies and with the fenestral (F) facies (G-F relationship in Fig. 3c). In particular, Gg-Fpg and Gwp-Fm lateral relationships are observed.

The remarkable predominance of gastropods, intercalations of marl and lateral associations with the fenestral facies indicate that the $\mathrm{G}$ facies probably corresponds to restricted ponds within the intertidal belt or to a restricted lagoon facies. Although there is not a good control of the lateral extent of this facies (see unit $\mathrm{G}$ in Fig. 3b), its relationship with the backshoal/washover $P$ facies and with the intertidal $\mathrm{F}$ facies supports both interpretations. Textural differences and varying proportions of skeletal and non-skeletal grains

\begin{tabular}{|l|l|l|l|l|}
\hline Journal : Large 10347 & Article No : 521 & Pages : 23 & MS Code : FACI-D-17-00067 & Dispatch : 23-1-2018 \\
\hline
\end{tabular}



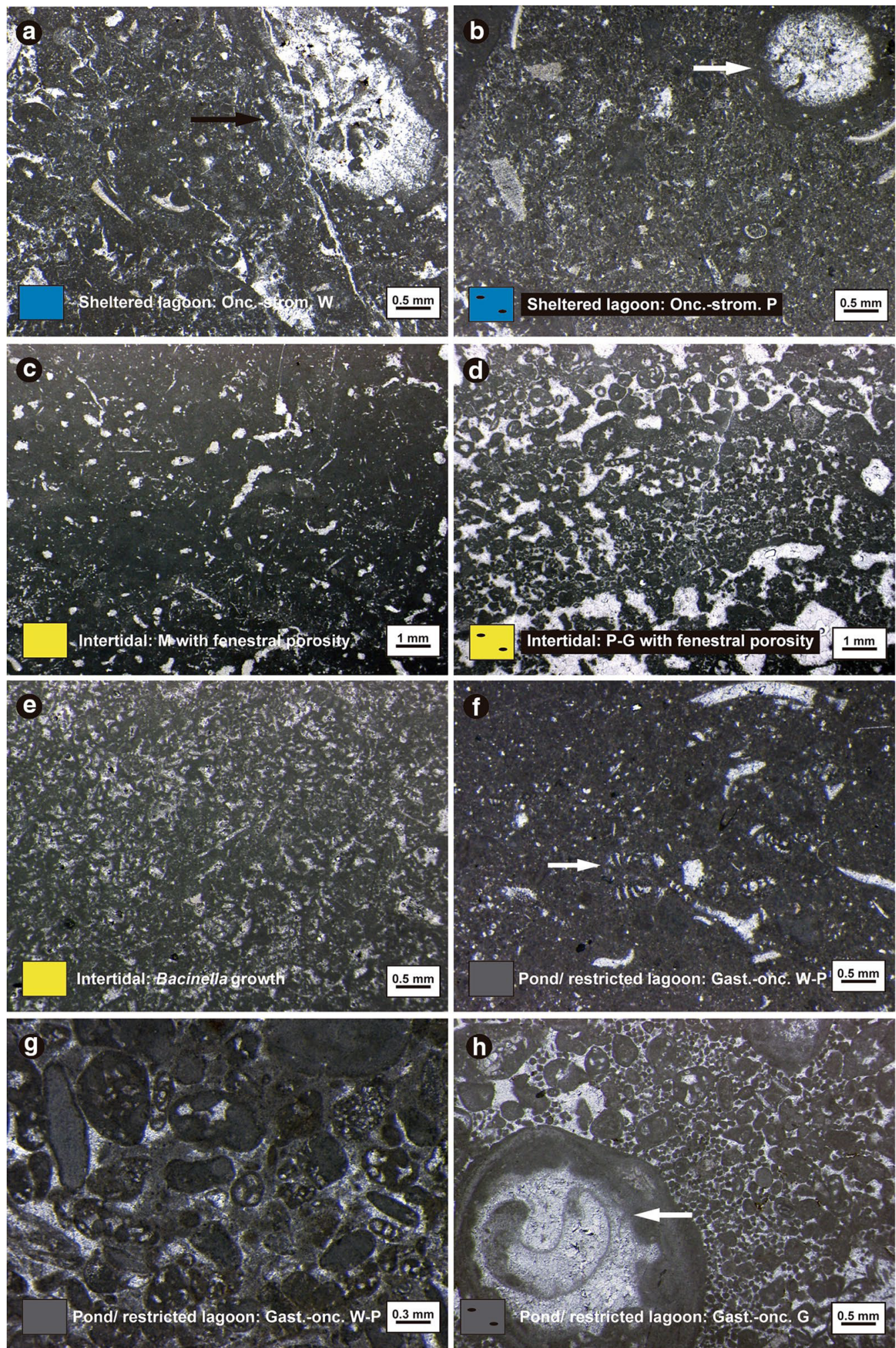

Fig. 6 a, b Oncolitic-stromatoporoid wackestone (a) and packstone (b) subfacies (sheltered lagoon subenvironment); the arrows indicate type II oncoids with bioclastic cores (corals) and thin crusts with grumose laminae. c, d Fenestral pores (intertidal subenvironment) in peloidal mudstone (c) and packstone-grainstone (d) layers. Note the dome-like stromatolitic structure formed by the fenestral porosity in d. e Bacinella growth in fenestral facies. $\mathbf{f}-\mathbf{h}$ Gastropod-oncolitic

facies (pond/restricted lagoon subenvironment). Lituolids are common in gastropod-oncolitic wackestone-packstone subfacies (white arrow in $\mathbf{f}$ ), and components are usually micritized $(\mathbf{g}) ; \mathbf{h}$ Well-sorted peloids, micritized bioclasts and ooids and type II oncoids in gastropod-oncolitic grainstone subfacies, with mainly gastropods as bioclastic cores (white arrow) 

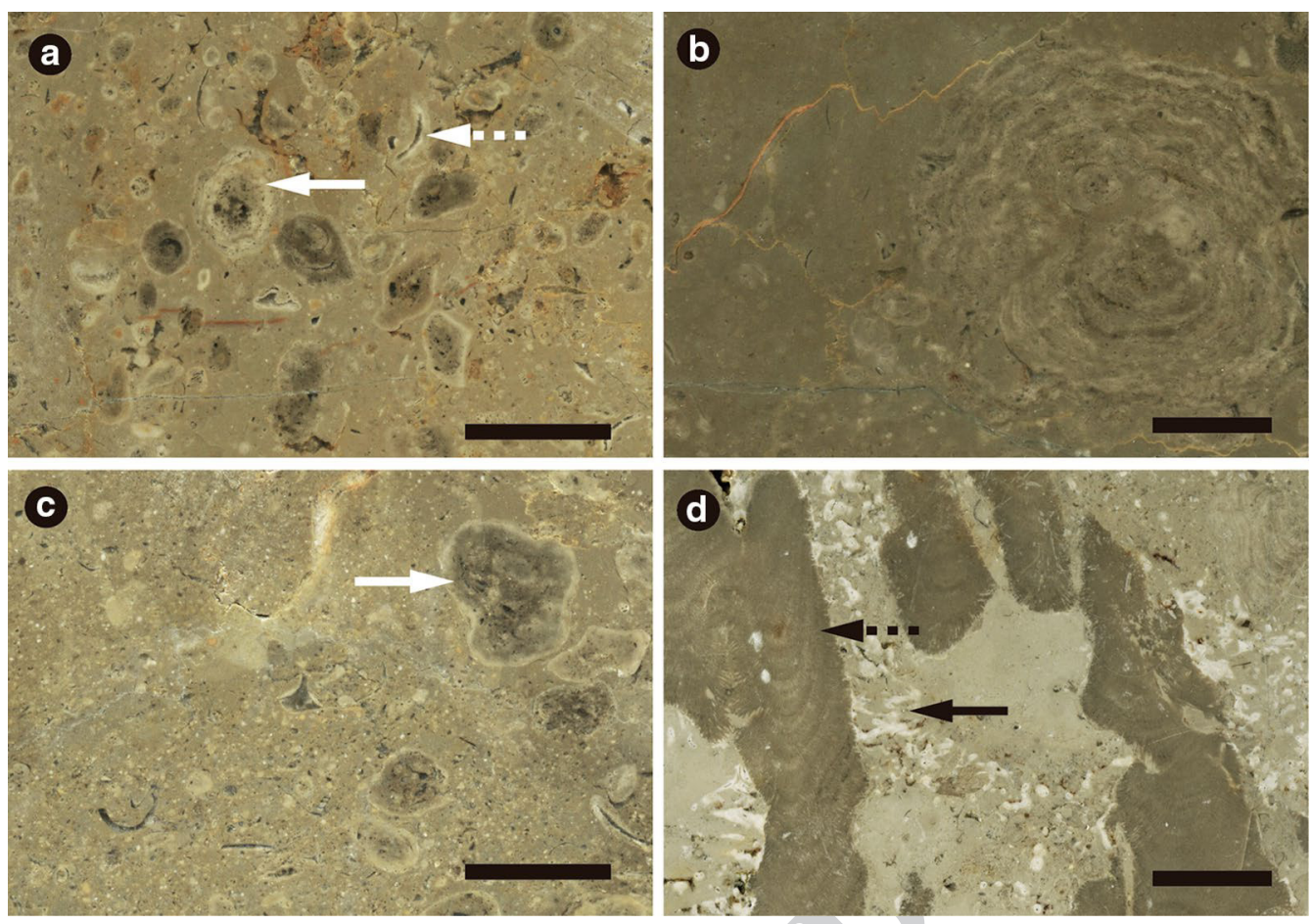

Fig. 7 a-c Polished slabs showing the different types of oncoids which characterize these facies. Type I and II oncoids (dashed and white arrows in a, respectively) are common in peloidal, oncoliticstromatoporoid and gastropod-oncolitic facies. Type III oncoids are characteristic of oncolitic facies, and also appear in oncolitic-stro-

between the Gg and Gwp subfacies are due to the influence of the surrounding sediment from the grain-supported and mud-supported fenestral facies and peloidal facies with which it is laterally related. Components accumulated in cmthick laminae reflect grains resedimented during high-energy events, probably storms. Locally intercalated marl indicates periods of higher detrital input, when carbonate production is reduced or diluted.

\section{Facies mosaic and sedimentary evolution}

The sedimentary model for the uppermost Kimmeridgian-lower Tithonian platform in the Mezalocha outcrops reflects a facies mosaic instead of continuous parallel-subparallel facies belts (Fig. 8a), as revealed by the detailed facies mapping following the 7 sedimentary units $(A-G$ in Figs. 3 and $8 b$ ). The detailed facies maps in Fig. $8 \mathrm{~b}$ also include the isopach lines for the successive sedimentary units (without decompaction, as W-P textures mostly dominate) to unravel the possible relationships of facies and variations in thickness.

At a long-term scale, the studied upper succession of the Higueruelas Fm reflects a shallowing-upward trend, from matoporoid facies (b). Type IVS oncoids (white arrow in c) appear especially in gastropod-oncolitic W-P subfacies, and also in peloidal W-P subfacies. d Cladocoropsis-type stromatoporoid in stromatoporoid facies (dashed arrow). Tubiphytes-Crescentiella encrustations (black arrow) usually grow around stromatoporoids. Scale bar is $1 \mathrm{~cm}$

backshoal/washover and sheltered lagoon to intertidal and pond/restricted lagoon subenvironments. Units A and B show that the sheltered lagoon developed to the northwest, with a predominance of oncolitic $\mathrm{O}$ facies, with Ow subfacies located in the more internal and protected areas of the lagoon. The backshoal/washover P facies is located to the southeast and locally includes small patches of stromatoporoid $\mathrm{S}$ (around $300 \mathrm{~m}$ in extent) and oncolitic-stromatoporoid OS facies. This facies distribution is consistent with the general paleogeographic reconstruction indicating the distal facies located to the southeast (see Fig. 1b). In units $\mathrm{C}$ to $\mathrm{E}$, the oncolitic $\mathrm{O}$ facies is considerably reduced, and stromatoporoid $\mathrm{S}$ facies patches dominate. These patches are more than $500 \mathrm{~m}$ in lateral extent and grade laterally mainly to oncolitic-stromatoporoid OS facies. In addition, the backshoal/washover facies is minor in extent compared with the initial units, and patches of the fenestral $\mathrm{F}$ facies developed mainly related to backshoal/washover peloidal (P) deposits and the OS facies (200 m to more than $500 \mathrm{~m}$ in lateral extent). In units $\mathrm{F}$ and $\mathrm{G}$, there is a widespread development of the intertidal subenvironment represented by the fenestral facies, laterally associated with the backshoal/ washover facies and local patches of pond/restricted lagoon gastropod-oncolitic $\mathrm{G}$ facies, thus representing the final

\begin{tabular}{|l|l|l|l|l|}
\hline Journal : Large 10347 & Article No : 521 & Pages : 23 & MS Code : FACI-D-17-00067 & Dispatch : 23-1-2018 \\
\hline
\end{tabular}


shallowing episode in the studied area. As regards variations in thickness, there is a progressive increase in thickness from the backshoal/washover environment to the sheltered lagoon facies (e.g., $1-3 \mathrm{~m}$, respectively, in units $\mathrm{C}$ to $\mathrm{D}$ ). The average thickness is reduced and more homogeneous in the latest units dominated by the intertidal $\mathrm{F}$ facies (around $2 \mathrm{~m}$ in units $\mathrm{E}$ and $\mathrm{F}$ ).

In summary, the backshoal/washover facies is present in all the sedimentary episodes, and changes laterally to almost all facies, since it is the result of the resedimentation of oolitic, peloidal and oncolitic shoals. Within the lagoon area, which records the highest sedimentary thickness, there is a predominance of oncolitic (type III oncoids) facies in the units A and B, but of stromatoporoid and oncolitic-stromatoporoid facies in units $\mathrm{C}$ to $\mathrm{E}$. Fenestral facies evolve from local patches in units $\mathrm{C}$ to $\mathrm{E}$, to a wide intertidal belt in units $\mathrm{F}$ and $\mathrm{G}$, with local development of ponds in the intertidal area or restricted lagoon. The spatial relationships of the facies across successive evolutionary units reflect a facies mosaic. In particular, stromatoporoid (S) and fenestral (F) facies clearly show a patchy distribution, with facies patches locally more than $500 \mathrm{~m}$ in lateral extent.

\section{Discussion}

\section{Factors controlling the mosaic distribution}

A combination of several internal and external factors controlled the facies heterogeneity in the studied inner ramp facies, including the long-term regional fall in sea-level, along with the irregular bottom topography, substrate stability and variable water energy. As regards the internal dynamics of the platform, one of the key factors increasing the variability and extent of facies is the presence of an irregular topography (Kerans and Tinker 1997; Della Porta et al. 2002; Hillgärtner 2006). Oolitic, peloidal and oncolitic shoals seaward of the lagoon acted as barriers for water energy, and controlled the occurrence of more protected areas, where low-energy conditions favored the development of oncolitic, stromatoporoid and oncolitic-stromatoporoid facies. The irregular topography is also determined by the input of resedimented material from the outer banks or shoals: storm-induced flows lead to abrupt changes in facies distribution by redistributing sediment in large quantities (i.e., washover deposits, see Fig. 8a) and by creating barriers between depositional subenvironments (Strasser and Védrine 2009), thus controlling the spatial and lateral extent of the lagoon facies. Within the sheltered lagoon, the patchy distribution of stromatoporoid facies reflects areas of preferential growth for stromatoporoids that were probably related with local hard substrates and areas with higher-energy hydrodynamic conditions that occurred in corridors created between the peloidal washovers (e.g., unit D in Fig. 8b). The greater thickness of the lagoon facies compared to the backshoal/washover peloidal facies (e.g., sedimentary units $\mathrm{B}$ to $\mathrm{D}$ in Fig. 8b) can be interpreted as a combination of the variable depositional depth or topography (i.e., relatively deeper lagoon areas) and differences in carbonate accumulation, which was potentially higher in the lagoon than in the backshoal area subjected to erosion by high-energy events. Small changes in depositional depth after the deposition of washover deposits would control the generation of fenestral facies patches in sedimentary units $\mathrm{C}$ to $\mathrm{E}$ (see Fig. 8).

External factors also contribute to facies evolution and their heterogeneity. Fluctuations in climate and regional sea-level become important factors that lead to changes in the composition and distribution of the depositional subenvironments, generated by variations in water energy, water temperature, transparency, nutrient availability and sediment input, which control the ecology of carbonate-producing organisms (e.g., Védrine et al. 2007; Strasser and Védrine 2009). Most of the skeletal content that characterizes the studied facies (e.g., dasycladacean algae, bivalves, brachiopods, echinoderms), as well as the types of oncoids and ooids, indicate normal salinity, oligotrophic conditions and good water transparency (e.g., Strasser 1984; Flügel 2004). In this respect, the low siliciclastic input (and reduced nutrient input) contributed to the extensive generation of type III oncoids, characterized by light-dependence and oligotrophic micro-encrusters (e.g., Leinfelder et al. 1993; Dupraz and Strasser 1999). Stromatoporoid facies, arranged in patches in the lagoon, also indicates good water transparency and oligotrophic conditions (Bádenas et al. 2010), but also a higher tolerance to water energy, salinity and water temperature (Leinfelder et al. 2005). However, in the case under study it is unlikely that variations in salinity and/or water temperature determined the widespread development of the stromatoporoid and oncolitic-stromatoporoid facies within the lagoon, since most of the defined facies include a similar bioclastic (normal marine) association (Table 1). Thus, the change from predominantly oncoid generation (units A and B) to a widespread development of stromatoporoid and oncolitic-stromatoporoid facies in units $\mathrm{C}$ to $\mathrm{E}$ (Fig. 8b) was related to higher-energy conditions driven by the long-term regional fall in sea-level, combined with the presence of encrusted surfaces and high-energy narrow corridors, rather than to changes in the paleoenvironmental conditions due to the climate.

\section{Implications of a facies mosaic in cyclostratigraphic analysis}

The stacking pattern of facies and their related depositional subenvironments are usually taken into account in cyclostratigraphy in order to define meter-scale 
high-frequency cycles. However, for shallow-marine carbonates, the intrinsic processes (depositional topography, hydrodynamic conditions, carbonate production and accumulation) variably interfere with the signal produced by external driving mechanisms (e.g., relative sea-level variations controlling accommodation, climate), thus reducing the potential for facies pattern predictability. Hence, vertical facies trend analysis may sometimes not be a reliable method of delimiting and correlating high-frequency cycles in shallow-marine stratigraphic successions, since different facies stacking patterns may be present within a cycle depending on the area of deposition (e.g., Verwer et al. 2009; Bádenas et al. 2010).

The identification and physical tracing of sharp bedding planes may serve as a useful tool for delimiting high-frequency cycles, since such bedding planes may represent sedimentary surfaces with no sedimentation or erosion linked to external driving mechanisms (i.e., potential cycle boundaries). For the studied sections in the Mezalocha outcrops, sharp bedding (isochronous) surfaces 1-6 would represent the cycle boundaries of the hypothetical elementary cycles A to $G$ that developed within the long-term regional-scale shallowing-upward sequence defined for the Higueruelas Fm (Ipas et al. 2004). The usual Fe-enrichment on these surfaces and the presence of local overlying $\mathrm{cm}$-thick marly beds support an interpretation of them as representing sedimentary surfaces with no sedimentation or erosion (Christ et al. 2012). Examples of the hypothetical cycles A to G in selected stratigraphic logs are shown in Fig. 9. It is noteworthy that the same high-frequency cycle can show variable thickness and vertical facies trends in areas very close to one another, i.e., cycles $\mathrm{B}$ and $\mathrm{C}$ are aggradational or shallowing-upward depending on the $\log$, and cycle D is aggradational in all the selected logs, except deepeningupward in log M5.

This lateral variability can be regarded as a consequence of the spatial complexity of the inner ramp environment, where internal factors interfere greatly with the more ordered signal of possible high-frequency sea-level cycles. Considering that there was no significant lateral variation in subsidence during deposition, the generally greater thickness of the sheltered lagoon facies within the hypothetical highfrequency cycles compared to the backshoal/washover peloidal facies (Fig. 8) can be interpreted as a combination of the variable depositional depth or topography (i.e., relatively deeper lagoon areas) with differences in carbonate accumulation, which is potentially higher in the lagoon compared to the backshoal area subjected to erosion by high-energy events. Another example of an internal factor is provided by event beds (peloidal washovers sharply intercalated within lagoon facies: e.g., sedimentary units $\mathrm{C}$ and D in Fig. 8b), which could create small elevated areas in the lagoon where discrete intertidal patches were generated, leaving corridors where relatively higher hydrodynamic conditions allowed the stromatoporoid patches to proliferate. Erosion due to a fall in base level linked to the high-frequency fall in sealevel, combined with sedimentary condensation at the initial stages of the rise in sea-level of the following cycle, would generate the sharp bedding surfaces bounding the high-frequency cycles.

Therefore, for larger-scale correlations of separated logs, recognition of these sharp bedding planes may serve as a useful tool for differentiating and correlating cycle boundaries. In this regard, correlation becomes easier for lower-frequency cycles, when additional tools for the identification of the same cycle can be used, such as a general vertical facies trend and the recognition of stratal patterns (e.g., stratathickening upward, strata-thinning or any particular stratal trend). At the level of the high-frequency sequences, correlation is sometimes difficult because their vertical facies stacking does not always display unequivocal deepeningshallowing or opening-closing trends, as seen for the sections studied in the Mezalocha outcrops, since autocyclic processes partly control facies evolution (Strasser 1991). Thus, if high-frequency cycles are to be used as a tool for cyclostratigraphic correlation, this should be preceded by a detailed analysis of the facies architecture of the cycles in selected continuous outcrops (e.g., Bádenas et al. 2010; Amour et al. 2011).

\section{Comparisons with other similar environments}

The spatial complexity of inner ramp facies has been deciphered for the uppermost Kimmeridgian-lower Tithonian Higueruelas Fm. The general paleogeographic distribution of facies, with the open-marine areas to the southeast, is coherent with the basin-wide paleogeographic reconstructions for Kimmeridgian-Tithonian times in northeastern Iberia (Aurell et al. 1994; Bádenas and Aurell 2001; see Fig. 1b). Some of these shallow carbonate facies have also been documented in other Upper Jurassic ramps of the Iberian Basin, showing similar spatial complexity of facies, especially for stromatoporoid facies. San Miguel et al. (2017) recognized levels with stromatoporoid boulders in the more proximal domain of the upper Kimmeridgian carbonate ramp in the Jabaloyas area of northeastern Spain, where higher-energy events (i.e., episodic storms) resulted in the accumulation of stromatoporoid boulder carpets along a paleoshoreline (lateral extent in the dip direction of the stromatoporoid-bearing layers of $2 \mathrm{~km}$ ). Pomar et al. (2015) documented the facies architecture and bedding patterns of the lower Kimmeridgian Pozuel Formation in the Moscardón and Frías de Albarracín outcrops, where landward of a high-energy cross-bedded oolitic facies belt, corals and stromatoporoids formed small patches, with microbial-dominated mounds with abundant

\begin{tabular}{|l|l|l|l|l|}
\hline Journal : Large 10347 & Article No : 521 & Pages : 23 & MS Code : FACI-D-17-00067 & Dispatch : 23-1-2018 \\
\hline
\end{tabular}




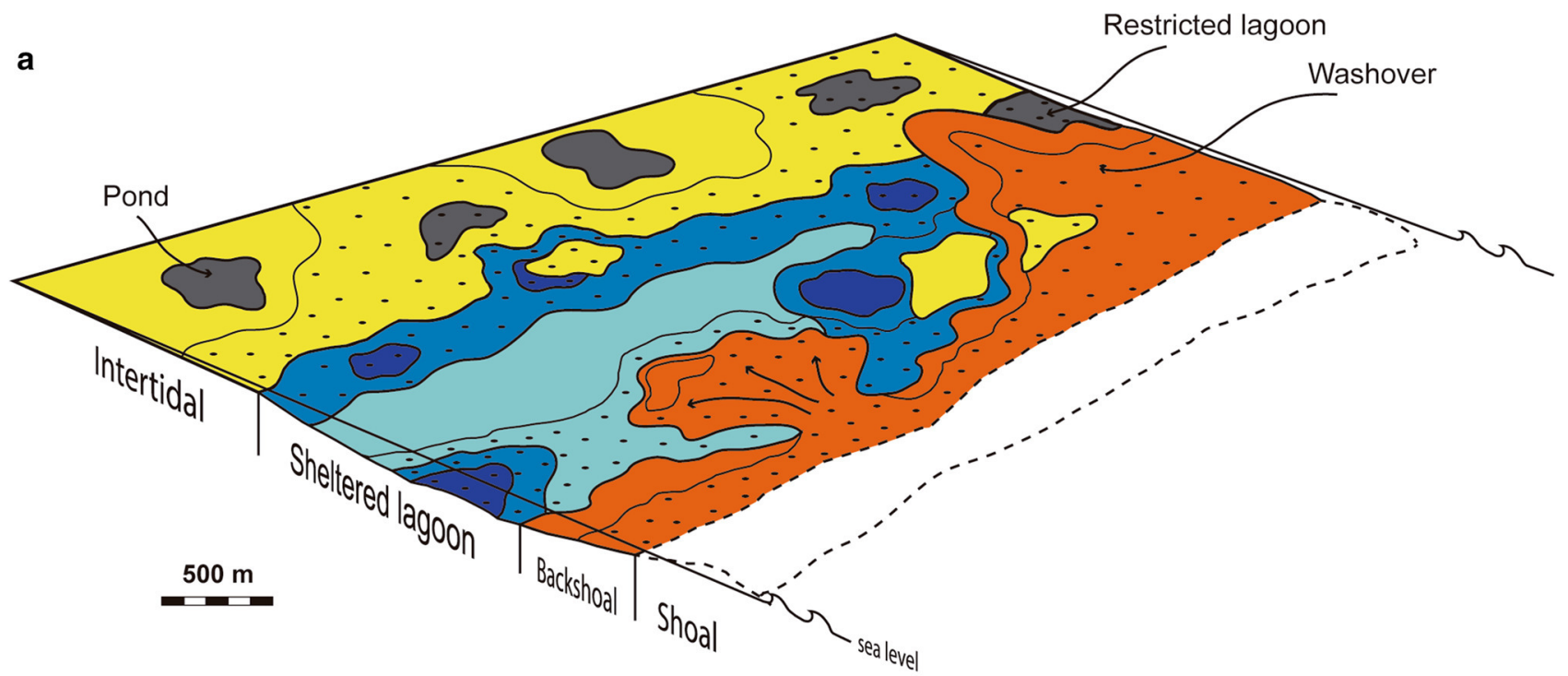

\section{FACIES AND SUBENVIRONMENTS}

Sheltered lagoon

$\square$ Oncolitic W (Ow)

Oncolitic-stromatoporoid W

Backshoal/washover Pond/ restricted lagoon Intertidal

- Oncolitic P (Op) - Oncolitic-stromatoporoid P

(OSp)

UNIT A
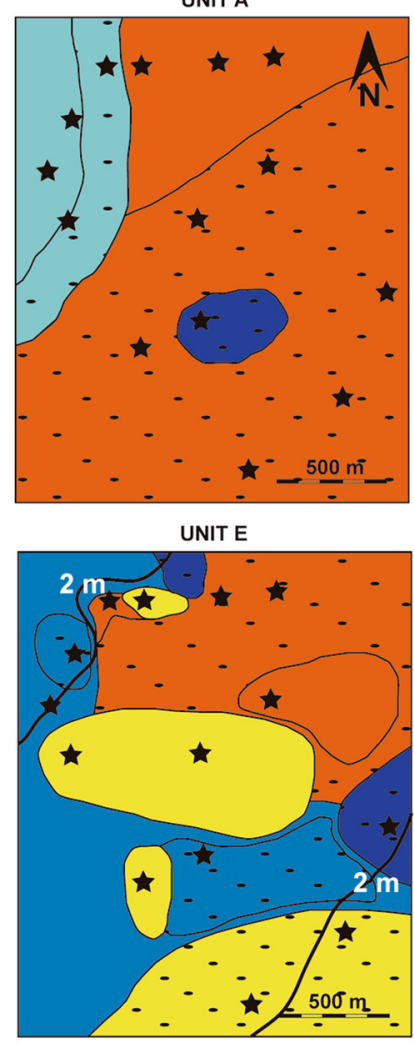
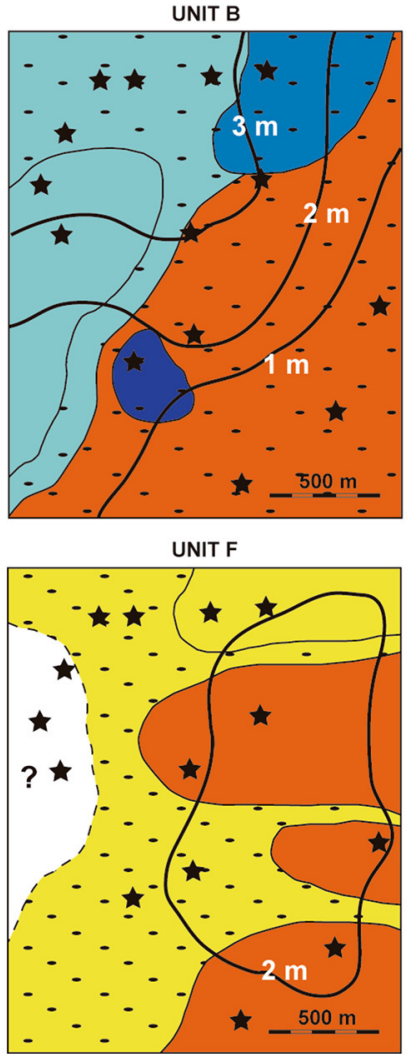

UNIT C

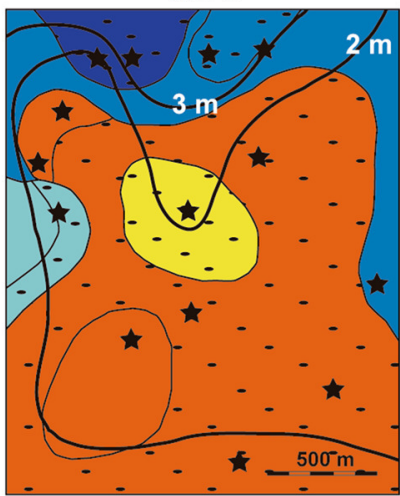

UNIT G

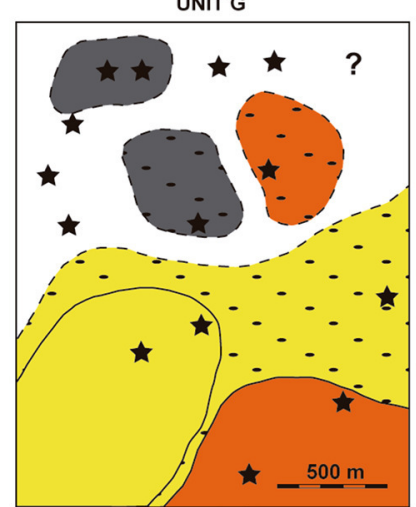

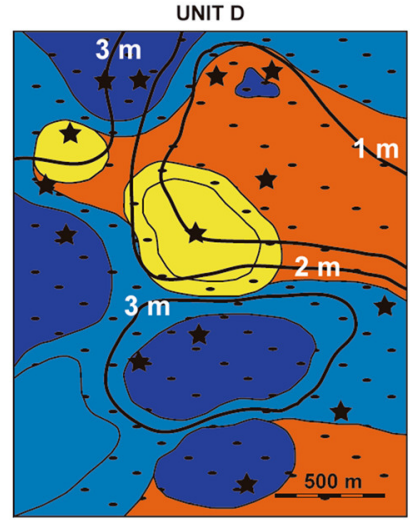

Studied sections

1-3 $\mathrm{m}$ Isopach lines

\begin{tabular}{|l|l|l|l|l|}
\hline Journal : Large 10347 & Article No : 521 & Pages : 23 & MS Code : FACI-D-17-00067 & Dispatch : 23-1-2018 \\
\hline
\end{tabular}


4Fig. 8 a Sedimentary model showing the facies distribution of the carbonate ramp in the Mezalocha outcrops around the Kimmeridgian-Tithonian transition. b Successive facies maps reconstructed for the seven sedimentary units identified within the studied succession. Isopach lines (1-3) for each sedimentary unit are also included except for sedimentary units A and G (no control of thickness)

Tubiphytes-Crescentiella in the innermost parts. These mounds are a few meters thick and are amalgamated, forming dip-oriented ribbons of mounds surrounded by bioclastic and intraclastic sediment controlled by up- and downcurrents. Patches of stromatoporoids, with a lateral extent of more than $500 \mathrm{~m}$, have been recognized in the studied Mezalocha outcrops, in corridors within the lagoon, where the currents would have probably been constrained (e.g., sedimentary unit D in Fig. 8b).

For subtidal carbonate environments in other Jurassic outcrops outside the Iberian Basin, remarkable similarities can also be found between some facies observed in the upper part of the Higueruelas Fm and some defined for the upper Kimmeridgian carbonate ramp deposits of the Arab-D Formation (Persian Gulf, Saudi Arabia; Ayoub and En Nadi 2000; Al-Saad and Ibrahim 2005), which represents the largest oil reservoir in the world (Al-Awwad and Collins 2013). The Arab-D carbonates consist mainly of well-sorted oolitic packstone-grainstone, deposited in active shoals and stromatoporoid-dominated patch reefs in the foreshoal environment (Grötsch et al. 2003). However, a significant difference from the studied strata around Mezalocha is the presence of large-scale stromatoporoid reefs, arranged as belts instead of patches. Lehmann et al. (2010) recognized meter-thick stromatoporoid buildups from middle to outer ramp areas of the Upper Jurassic carbonate platform in offshore Abu Dhabi (eastern Saudi Arabia), more than $3 \mathrm{~km}$ in lateral extent. For the inner to outer carbonate ramp of onshore Abu Dhabi, sedimentological analysis indicates that stromatoporoid fragments are a key component in the lagoon, but no bioconstructions are recognized (Marchionda et al. 2018). The quality of this reservoir is due to the interparticle porosity in peloidal and oolitic grainstone and the great porosity resulting from the dissolution of stromatoporoid bioclasts. Consequently, for hydrocarbon prospecting campaigns, it is important to take into account the variable lateral extent of stromatoporoid facies in accordance with the characteristics of subtidal environments.

Other examples where the complexity and spatial limitations of stromatoporoid-dominated deposits are also revealed occur in Paleozoic carbonate platforms. Sandström and Kershaw (2002) documented decimeter- to meter-scale stromatoporoid-dominated biostromes in the inner areas of a rimmed carbonate platform of the Ludlow-age Hemse Group (Silurian) in the eastern Gotland (Sweden), which represent one of the world's richest Paleozoic stromatoporoid deposits.
The lateral extent of these biostromes varies from a few tens of meters to more than $1 \mathrm{~km}$. Smaller bioconstructions are found in the lagoonal deposits of a mixed carbonate-siliciclastic ramp in the upper Devonian Alexandra Reef System (Canada; MacNeil and Jones 2016), where clearly defined meter-scale stromatoporoid bioherms measuring 10 to $30 \mathrm{~m}$ in lateral extent are recognized.

\section{Conclusions}

In order to establish correlations of facies and sedimentary cycles at the kilometer scale, detailed facies analysis is required to decipher whether shallow-water carbonate deposits correspond to facies belts or facies mosaics. In this work, the spatial relationship and lateral continuity of the facies ascertained for the uppermost Kimmeridgian-lower Tithonian inner carbonate ramp deposits of the Mezalocha outcrops (NE Spain) reflect a facies mosaic, instead of continuous parallel-subparallel facies belts.

Sedimentological analysis and detailed facies mapping of these inner carbonate ramp deposits resulted in the definition of 6 facies and 12 subfacies, which record the transition from backshoal/washover and sheltered lagoon to intertidal and pond/restricted lagoon subenvironments. The backshoal/washover deposits are characterized by peloidal (wackestone-packstone and grainstone) facies, with lithic peloids and variable proportions of ooids and oncoids resedimented from oolitic-peloidal and oncolitic shoals. The sheltered lagoon deposits include oncolitic, stromatoporoid and oncolitic-stromatoporoid (wackestone and packstone) facies. The oncolitic facies is dominated by type III oncoids, formed predominantly during low-energy periods (microbial laminae) alternating with short high-energy episodes (micritic laminae). The stromatoporoid facies presents variable proportions of both in situ and reworked stromatoporoids, with the common presence of corals and chaetetids. This facies occurs in different positions within the lagoon, and grades laterally to oncolitic-stromatoporoid facies, characterized by type I, II and III oncoids and fragments of stromatoporoids. The intertidal subenvironment is represented by mudstone and packstone-grainstone with fenestral facies. The gastropod-oncolitic wackestone-packstone and grainstone facies, intercalated with marl, may represent local ponds in the intertidal area or a restricted lagoon.

The studied succession reflects a general shallowingupward trend. Seven sedimentary units, reflecting significant changes in facies, were recognized: from dominant oncolitic facies in the initial units A and B; stromatoporoid and oncolitic-stromatoporoid facies in units $\mathrm{C}$ to $\mathrm{E}$; and intertidal and pond/restricted lagoon subenvironments in units $\mathrm{F}$ and $\mathrm{G}$. The backshoal/washover facies is present in all the sedimentary units. The spatial distribution of

\begin{tabular}{|l|l|l|l|l|}
\hline Journal : Large 10347 & Article No : 521 & Pages : 23 & MS Code : FACI-D-17-00067 & Dispatch : 23-1-2018 \\
\hline
\end{tabular}




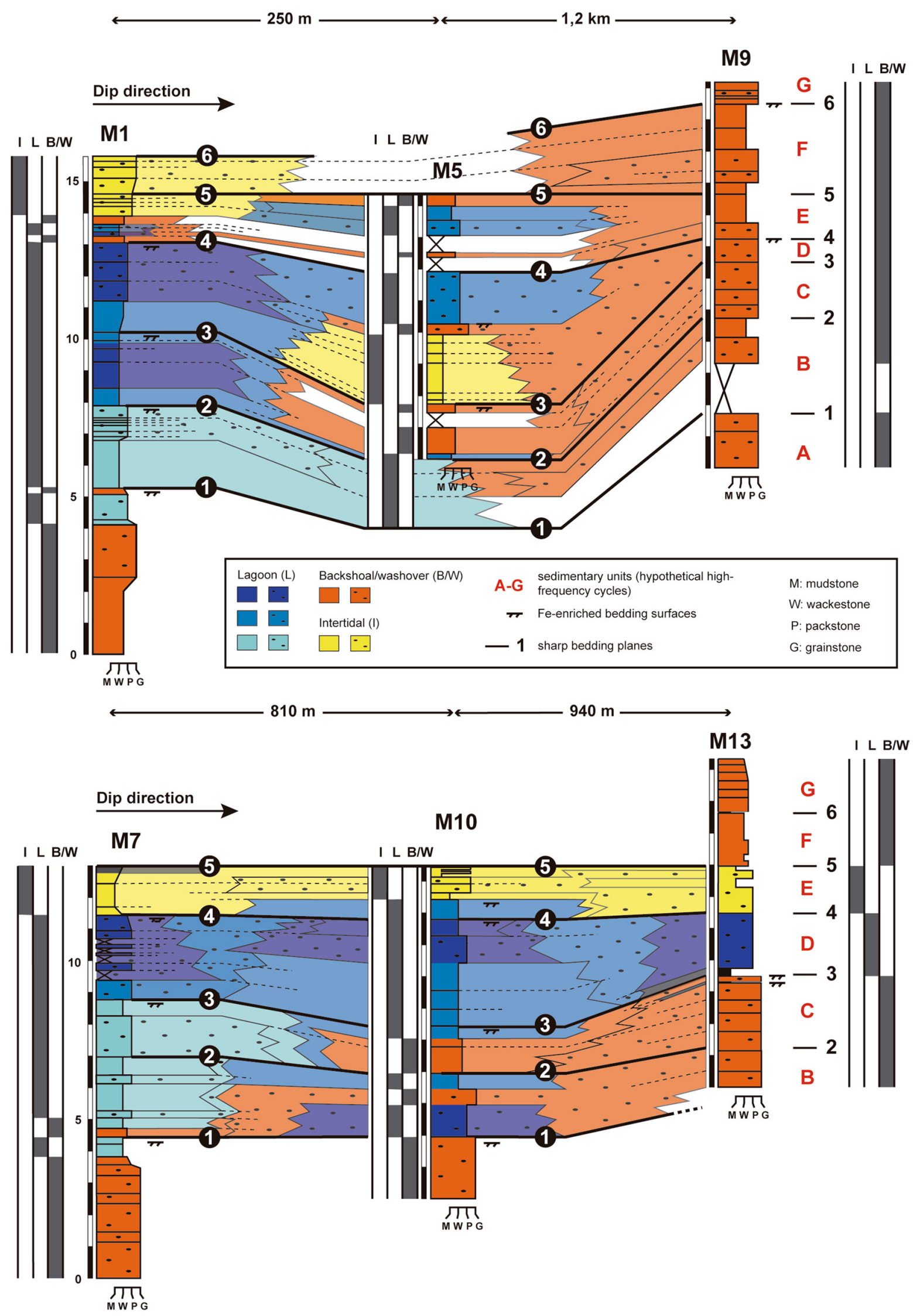


4Fig. 9 Correlation of the hypothetical high-frequency cycles (A-G) recognized in M1-M5-M9 and M7-M10-M13 transects, defined by the presence of sharp bedding planes, and the vertical evolution of the subenvironments. Notice that the vertical facies evolution in a single high-frequency cycle may show significant variation from one log to another

facies indicates a facies mosaic instead of continuous parallel-subparallel facies belts. In particular, stromatoporoid and fenestral facies show a patchy distribution, facies patches being locally more than $500 \mathrm{~m}$ in lateral extent. This patchy distribution was controlled by internal and external factors. Sheltered lagoon facies developed in the protected area of external oolitic-peloidal and oncolitic shoals or banks, where the extensive generation of type III oncoids, characterized by light-dependence and oligotrophic micro-encrusters, was favored by the low siliciclastic input. The development of stromatoporoid-bearing patchy facies was controlled by higher-energy conditions related to the long-term regional fall in sea-level, combined with the presence of high-energy narrow corridors and local hard substrates. Storm action led to the deposition of backshoal and washover sediments that were locally exposed to form patches of fenestral facies.

The mosaic facies distribution ascertained in this work can provide useful tools for achieving reconstructions of depositional heterogeneities in similar settings, and an understanding of the factors controlling these facies mosaics may be relevant for the interpretation of the vertical stacking of facies in high-frequency cycles and for correlations of cycles at larger scales.

Acknowledgements This paper was funded by projects CGL201453548-P and CGL2017-85038-P of the Spanish Ministry of Science and Innovation and the H54 Research Group-IUCA Aragosaurus: recursos geológicos y paleoambientes, supported by the Gobierno de Aragón and the European Social Fund. The research of Cristina Sequero is funded by a FPU Grant (Spanish Ministry of Science and Innovation). We are grateful for the revision that has been done by Michele Morsilli, an anonymous reviewer and the Editor-in-Chief, Maurice Tucker. We also thank Rupert Glasgow for accepting to review the English quality.

\section{References}

Al-Awwad SF, Collins LB (2013) Arabian carbonate reservoirs: a depositional model of the Arab-D reservoir in Khurais field, Saudi Arabia. Am Assoc Pet Geol 97:1099-1119

Al-Saad H, Ibrahim M (2005) Facies and palynofacies characteristics of the Upper Jurassic Arab D reservoir in Qatar. Rev Paléobiol 24(1):225-241

Amour F, Mutti M, Christ N, Immenhauser A, Agar SM, Benson GS, Tomás S, Always R, Kabiri L (2011) Capturing and modelling metre-scale spatial facies heterogeneity in a Jurassic ramp setting (Central High Atlas, Morocco). Sedimentology 59:1158-1189
Aurell M, Meléndez A (1986) Sedimentología de la Formación Calizas con oncolitos de Higueruelas (Malm) en la región de MuelBelchite (Provincia de Zaragoza). Acta Geol Hisp 21-22:307-312

Aurell M, Meléndez A (1987) Las bioconstrucciones de corales y sus facies asociadas durante el Mal en la Cordillera Ibérica Central (prov. De Zaragoza). Estud Geol 43:261-269

Aurell M, Mas R, Meléndez A, Salas R (1994) El tránsito Jurásico-Cretácico en la Cordillera Ibérica: relación tectónica-sedimentación y evolución paleogeográfica. Cuad Geol Ibérica 18:369-396

Aurell M, Meléndez G, Olóriz F, Bádenas B, Caracuel J, García-Ramos JC, Goy A, Linares A, Quesada S, Robles S, Rodríguez-Tovar FJ, Rosales I, Sandoval J, Suárez de Centi C, Tavera JM, Valenzuela M (2002) The geology of Spain. Geological Society, London, pp 213-254

Aurell M, Robles S, Bádenas B, Rosales I, Quesada S, Meléndez G, García-Ramos JC (2003) Transgressive-regressive cycles and Jurassic palaeogeography of northeast Iberia. Sediment Geol 162:239-271

Aurell M, Bádenas B, Ipas J, Ramajo J (2010) Sedimentary evolution of an Upper Jurassic epeiric carbonate ramp Iberian Basin NE Spain. In: Buchem FSP, Gerdes KD, Esteban M (eds) Mesozoic and Cenozoic carbonate systems of the Mediterranean and the Middle East: stratigraphic and diagenetic reference models, vol 329. Geological Society, Special Publications, London, pp 89-111

Aurell M, Ipas J, Bádenas B, Muñoz A (2012) Distribución de facies con corales y estromatopóridos en el dominio interno de una plataforma carbonatada (Titónico, Cordillera Ibérica). Geogaceta 51:67-70

Ayoub R, En Nadi IM (2000) Stratigraphic framework and reservoir development of the Upper Jurassic in Abu Dhabi area, UAE. In: Alsharhan AS, Scott RW (eds) Middle East Models of Jurassic/ Cretaceous carbonate system, vol 69. SEPM Society for Sedimentary, Tulsa, pp 229-248

Bádenas B, Aurell M (2001) Kimmeridgian palaeogeography and basin evolution of northeastern Iberia. Palaeogeogr Palaeoclimatol Palaeoecol 168:291-310

Bádenas B, Aurell M (2010) Facies models of a shallow-water carbonate ramp based on distribution of non-skeletal grains (Kimmeridgian, Spain). Facies 56:89-110

Bádenas B, Aurell M, Rodríguez-Tovar FJ, Pardo-Igúzquiza E (2003) Sequence stratigraphy and bedding rhythms of an outer ramp limestone succession (Late Kimmeridgian, Northeast Spain). Sediment Geol 161:153-174

Bádenas B, Aurell M, Bosence D (2010) Continuity and facies heterogeneities of shallow carbonate ramp cycles (Sinemurian, Lower Jurassic, North-east Spain). Sedimentology 57:1021-1048

Burchette TP, Wright VP (1992) Carbonate ramp depositional systems. Sediment Geol 79:3-57

Burgess PM, Emery DJ (2004) Sensitive dependence, divergence and unpredictable behaviour in a stratigraphic forward model of a carbonate system. In: Curtis A, Wood R (eds) Geological prior information: informing science and engineering, vol 239. Geological Society, Special Publications, London, pp 77-94

Burgess PM, Wright VP (2003) Numerical forward modeling of carbonate platform dynamics: an evaluation of complexity and completeness in carbonate strata. J Sediment Res 73(5):637-652

Cepriá JJ, Bádenas B, Aurell M (2002) Evolución sedimentaria y paleogeografía del Jurásico Superior (Kimmeridgiense superiorTitónico) en la Sierra de Arcos (Cordillera Ibérica). J Iber Geol 28:93-106

Christ N, Immenhauser A, Amour F, Mutti M, Tomás S, Agar SM, Always R, Kabiri L (2012) Characterization and interpretation of discontinuity surfaces in a Jurassic ramp setting (High Atlas, Morocco). Sedimentology 59:249-290

Dahanayake K (1977) Classification of oncoids from the Upper Jurassic carbonates of the French Jura. Sediment Geol 18:337-353

\begin{tabular}{|l|l|l|l|l|}
\hline Journal : Large 10347 & Article No: 521 & Pages : 23 & MS Code : FACI-D-17-00067 & Dispatch : 23-1-2018 \\
\hline
\end{tabular}


Della Porta G, Kenter JAM, Immenhauser A, Bahamonde J (2002) Lithofacies character and architecture across a Pennsylvanian inner-platform transect (Sierra de Cuera, Asturias, Spain). J Sediment Res 72:898-916

Dercourt J, Ricou L, Vrielynck B (1993) Atlas Tethys palaeoenvironmental maps. CCGM, Paris

Drummond CN, Wilkinson BH (1993) Aperiodic accumulation of cyclic peritidal carbonate. Geology 21:1023-1026

Dunham RJ (1962) Classification of carbonate rocks according to depositional texture. Am Assoc Pet Geol Mem 1:108-121

Dupraz C, Strasser A (1999) Microbialites and micro-encrusters in shallow coral bioherms (Middle to Late Oxfordian, Swiss Jura mountains). Facies 40:101-129

Flügel E (1974) Fazies-Interpretation der Cladocoropsis-Kalke (Malm) auf Karaburun, W-Anatolien. Arch Lagerstätt-Forsch Ostalpen Sd-Bd 2:79-94

Flügel E (2004) Microfacies of carbonate rocks: analysis, interpretation and application. Springer, Berlin, p 976

Ginsburg RN (1971) Landward movement of carbonate mud: new model for progressive cycles in carbonates. AAPG Bull 55:340

Gischler E, Lomando AJ (1999) Recent sedimentary facies of isolated carbonate platforms, Belize-Yucatan system, Central America. J Sediment Res 69(3):747-763

Goldhammer RK, Dunn PA, Hardie LA (1990) Depositional cycles, composite sea-level changes, cycle stacking patterns, and the hierarchy of stratigraphic forcing: examples from Alpine Triassic platform carbonates. Geol Soc Am Bull 102:535-562

Grötsch J, Suwaina O, Ajlani G, Taher A, El-Khassawneh R, Lokier S, Coy G, van der Weerd E, Masalmeh S, van Dorp J (2003) The Arab Formation in central Abu Dhabi: 3-D reservoir architecture and static and dynamic modelling. GeoArabia Gulf PetroLink Bahrain 8(1):47-86

Hernández-Samaniego A, Ramírez-Merino JI (2005) Mapa Geológico y Memoria explicativa, Hoja Escala 1:50.000 de Longares (411). In: IGME (ed), pp 97

Hillgärtner H (2006) High-resolution correlation in Cretaceous platform carbonates of the Middle East: rules to solve the puzzle? In: AAPG European Region conference: Architecture of carbonate systems through time, Mallorca 2006, Program Book 26

Ipas J, Aurell M, Bádenas B (2004) Ambientes sedimentarios y secuencias en la Fm. Higueruelas (Jurásico Superior) en la Cordillera Ibérica Septentrional. Geogaceta 35:7-10

Ipas J, Aurell M, Bádenas B, Canudo JI, Liesa C, Mas JR, Soria AR (2007) Caracterización de la Formación Villar del Arzobispo al sur de Zaragoza (Titónico, Cordillera Ibérica). Geogaceta 41:111-114

Jones B, Desrochers A (1992) Shallow platform carbonates. In: Walker RG, James NP (eds) Facies models: response to sea level change. Geol Assocs Can, St. John's, pp 277-301

Kerans C, Tinker SW (1997) Sequence stratigraphy and characterization of carbonate reservoirs: SEMP Short Courses Notes 40. SEMP, Tulsa, p 130

Lehmann CT, Al Hosany KI, Matarid T, Sayed MI (2010) Addressing reservoir heterogeneities in the Development of Upper Jurassic Carbonate Reservoirs, offshore Abu Dhabi. Society of Petroleum Engineers, SPE 137888, Abu Dhabi

Lehrmann DJ, Goldhammer RK (1999) Secular variations in parasequence and facies stacking patterns of platform carbonates: a guide to application of stacking-patterns analysis in strata of diverse ages and settings. In: Harris PM, Saller AH, Simo JA (eds) Advances in carbonate sequence stratigraphy: application to reservoirs, outcrops, and models, vol 63. SEPM Special Publication, Tulsa, pp 187-226

Leinfelder RR, Nose M, Schmid D, Werner M (1993) Microbial crusts of the Late Jurassic: composition, palaeoecological significance and importance in reef construction. Facies 29:195-230
Leinfelder RR, Schlagintweit F, Werner W, Ebli O, Nose M, Schmid D, Hughes G (2005) Significance of stromatoporoids in Jurassic reefs and carbonate platforms_concepts and implications. Facies 51:287-325

MacNeil AJ, Jones B (2016) Stromatoporoid growth forms and Devonian reef fabrics in the Upper Devonian Alexandra Reef System, Canada-insight on the challenges of applying Devonian reef facies models. Sedimentology 63:1425-1457

Marchionda E, Deschamps R, Gobianchi M, Nader FH, Di Giulio A, Morad DJ, Al Darmaki F, Ceriani A (2018) Field-scale depositional evolution of the Upper Jurassic Arab Formation (onshore Abu Dhabi, UAE). Mar Pet Geol 89:350-369

Muñoz A, Arenas C, González A, Luzón A, Pardo G, Pérez A, Villena J (2002) Ebro Basin (northeastern Spain). In: Gibbons W, Moreno MT (eds) The geology of Spain. Geological Society, London, pp 301-309

Pomar L (2001) Types of carbonate platforms: a genetic approach. Basin Res 13:313-334

Pomar L, Aurell M, Bádenas B, Morsilli M, Al-Awwad SF (2015) Depositional model for a prograding oolitic wedge, Upper Jurassic, Iberian basin. Mar Pet Geol 67:556-582

Pratt BR, James NP (1986) The St. George Group (Lower Ordovician) of western Newfoundland: tidal flat island model for carbonate sedimentation in shallow epeiric seas. Sedimentology 33:313-343

Rankey EC (2002) Spatial patterns of sediment accumulation on a Holocene carbonate tidal flat Northwest Andros Island, Bahamas. J Sediment Res 72:591-601

Rankey EC (2016) On facies belts and facies mosaics: Holocene isolated platforms, South China Sea. Sedimentology 63:2190-2216

Rankey EC, Reeder SL (2010) Controls on platform-scale patterns of surface sediments, shallow Holocene platforms, Bahamas. Sedimentology 57:1545-1565

Read JF (1985) Carbonate platform facies models. AAPG Bull 69:1-21

Riegl B, Piller WE (1999) Coral frameworks revisited-reefs and corals carpets in the northern Red Sea. Coral Reefs 18:241-253

San Miguel G, Aurell M, Beatriz B (2017) Occurrence of high-diversity metazoan- to microbial-dominated bioconstructions in a shallow Kimmeridgian carbonate ramp (Jabaloyas, Spain). Facies 63:13

Sandström O, Kershaw S (2002) Ludlow (Silurian) stromatoporoid biostromes from Gotland, Sweden: facies, depositional models and modern analogues. Sedimentology 49:379-395

Schlager W (2000) Sedimentation rates and growth potential of tropical, cool water and mud mound carbonate factories. In: Insalaco E, Skelton PW, Palmer TJ (eds) Carbonate platform systems: components and interactions, vol 178. Geology Society Specia Publications, London, pp 217-227

Schlager W (2003) Benthic carbonate factories of the Phanerozoic. Int J Earth Sci 92:445-464

Shinn EA (1968) Practical significance of birdseye structures in carbonate rocks. J Sediment Petrol 38:215-223

Strasser A (1984) Black-pebble occurrence and genesis in Holocene carbonate sediments (Florida Keys, Bahamas, and Tunisia). J Sediment Petrol 54(4):1097-1109

Strasser A (1986) Ooids in Purbeck limestones (lowermost Cretaceous) of the Swiss and French Jura. Sedimentology 33:711-727

Strasser A (1991) Lagoonal-peritidal sequences in carbonate environments: autocyclic and allocyclic processes. In: Einsele G, Ricken W, Seilacher A (eds) Cycles and events in stratigraphy. Springer, Berlin, pp 709-721

Strasser A, Védrine S (2009) Controls on facies mosaics of carbonate platforms: a case study from the Oxfordian of the Swiss Jura. In: Special publication of the International Association of Sedimentologists, vol 41, pp 199-213

Strasser A, Pittet B, Hillgärtner H, Pasquier JB (1999) Depositional sequences in shallow carbonate-dominated sedimentary 
systems: concepts for a high-resolution analysis. Sediment Geol 128:201-221

Turnsek D, Buser S, Ogorelec B (1981) An Upper Jurassic reef complex from Slovenia, Yugoslavia. In: Toomey DF (ed) European fossil reef models, vol 30. SEPM Special Publications, Tulsa, pp 361-369

Védrine S, Strasser A, Hug W (2007) Oncoid growth and distribution controlled by sea-level fluctuations and climate (Late Oxfordian, Swiss Jura Mountains). Facies 53(4):535-552

Verwer K, Della Porta G, Merino-Tomé O, Kenter JAM (2009) Control and predictability of carbonate facies architecture in a Lower Jurassic three-dimensional barrier-shoal complex (Djebel Bou Dahar, High Atlas, Morocco). Sedimentology 56:1801-1831
Wilkinson BH, Drummond CN (2004) Facies mosaic across the Persian Gulf and around Antigua-stochastic and deterministic products of shallow-water sediment accumulation. J Sediment Res 74:513-526

Wilkinson BH, Diedrich NW, Drummond CN (1996) Facies succession in peritidal carbonate sequences. J Sediment Res 66:1065-1078

Wilson JL (1975) Carbonate facies in geologic history. Springer, New York, $\mathrm{p} 471$

Wright VP, Burgess PM (2005) The carbonate factory continuum, facies mosaic and microfacies: an appraisal of some of the key concepts underpinning carbonate sedimentology. Facies 51:17-23 